\title{
Dietary Patterns Associated with Adult Obesity in Tehran, Iran: A Scoping Review
}

Nahid Zerafati-Shoae

PhD Candidate, Department of Nutrition, School of Public Health, Iran University of Medical Sciences, and Faculty of Nutrition Sciences and Food Technology, National Nutrition and Food Technology Research Institute, Shahid Beheshti University of Medical Sciences, Tehran, Iran.

Leila Azadbakht

Professor, Department of Community Nutrition, School of Nutritional Sciences and Dietetics, Tehran University of Medical Sciences, Tehran, Iran.

Farzaneh Asgari-Taee

PhD Candidate, Department of Nutrition, School of Public Health, Iran University of Medical Sciences, Tehran, Iran.

Mohammad Hosein Taghdisi Public Health Department, Faculty of Health and Medical Engineering, Tehran Medical Sciences, Islamic Azad University, Tehran, Iran.

Naheed Ariyaeian

* Associate Professor, Department of Nutrition, School of Public Health, and Research Center for Environmental Health Technology, Iran University of Medical Sciences, Tehran, Iran. (Corresponding Author)

aryaeian.n@iums.ac.ir

Received: 2021/05/21

Accepted: 2021/08/23

Doi: 10.52547/ijhehp.9.4.327

\section{ABSTRACT}

Background and Objective: Identification of obesity-related dietary patterns in any culture can affect policymaking. The purpose of the study was to summarize obesity-related dietary patterns and their food groups in Tehranian adults.

Materials and Methods: The study followed the five stages in the methodological framework proposed by Arksey and O'Malley. We searched international databases (PubMed, Web of Science), national databases (SID, Iran Doc) and Google Scholar search engine with the keywords obesity, overweight, dietary patterns, eating patterns, food patterns, diet and Iran for finding related studies that have been published in the last two decades (2000-2020) along with the manual search of the list of selected study sources and gray literature (dissertations and final research report).

Results: A total of 12 studies were included in the review study. 17 out of 33 dietary patterns were associated with obesity. Eight diets were undesirable, eight diets were desirable, and one was inconsistently associated with obesity. Food groups common in undesirable diets include sugar-sweetened beverages, sweets, desserts, industrial juices, sugar, red meat, processed meats, solid fats, refined grains, snacks. Food groups common in desirable diets include vegetables, fruits, poultry and fish, legumes, whole grains, olive or olive oil.

Conclusion: Obesity-related dietary patterns are common in adults in Tehran. This study provided information on food groups that guide targeted policymaking to improve the food groups in food store supply, household consumption, and food industry and agricultural products.

Keywords: food patterns, diet, healthy diet, unhealthy diet, overweight Paper Type: Research Article.

Citation (Vancouver): Zerafati-Shoae N, Azadbakht L, Asgari-Taee F, Taghdisi $\mathrm{MH}$, Ariyaeian N. Dietary Patterns Associated with Adult Obesity in Tehran, Iran: A Scoping Review. Iran J Health Educ Health Promot. Winter 2022;9(4): 327-349

Citation (APA): Zerafati-Shoae N., Azadbakht L., Asgari-Taee F., Taghdisi MH., Ariyaeian N. (Winter 2022). Dietary Patterns Associated with Adult Obesity in Tehran, Iran: A Scoping Review. Iranian Journal of Health Education \& Health Promotion., 9(4), 327-349. 


\section{الكَوهاى غذايى مرتبط با جاقىى بزرَّالان شهر تهران، ايران: مرور دامنه اى}

\section{جكيده}

زمينه و هدف : شناسايى الكوهاى غذايى مرتبط با حاقى بر سياستخذارى موثر است. هدف اين مطالعها، جمع

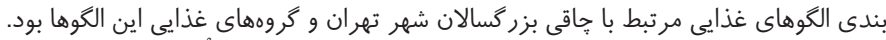

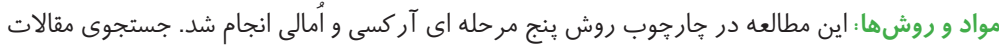

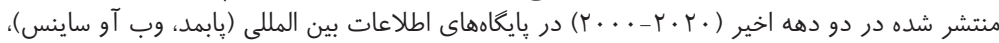

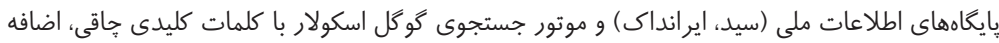

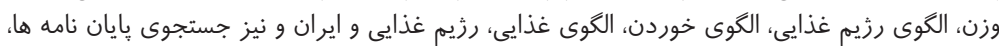

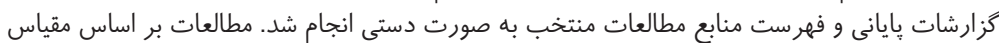

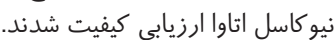

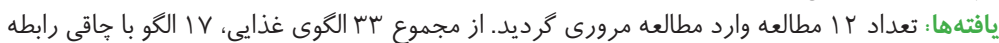

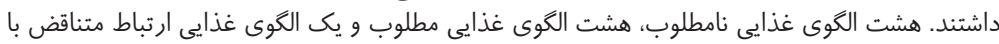

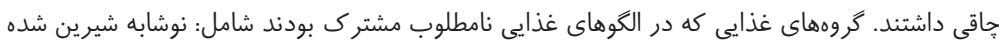

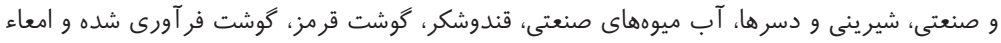

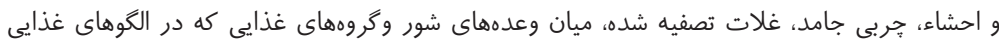

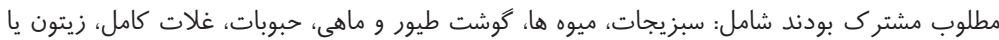

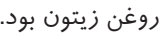

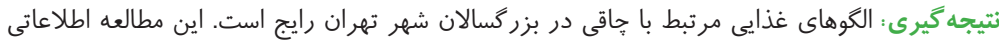

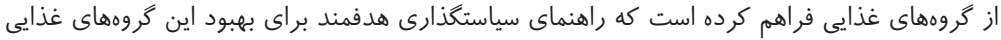

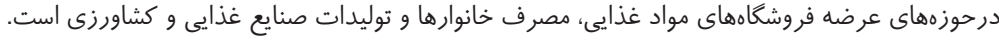

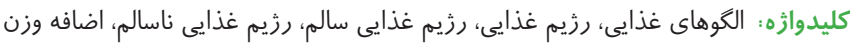

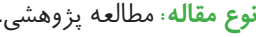

4 استناد (ونكوور) : ظر افتى شعاع ن، آزادبخت ل، عسكرى طائى ف، تقديسى م، آريائيان ن •. الكوهاى

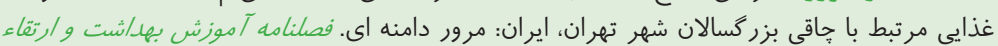

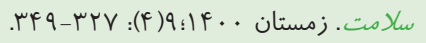

\استناد (APA): ظر افتى شعاع، ناهيد؛ آزادبخت، ليلا؛ عسكرى طائى، فرزانه؛ تقديسى، محمدحسين؛

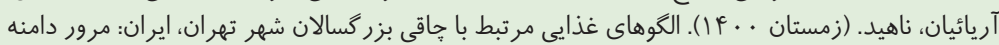

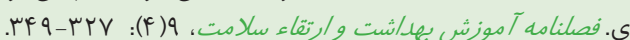


كاهش خطر جاقى شكمى بدليل ناهمكونى بسيار بالاى مطالعات

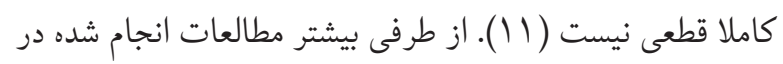

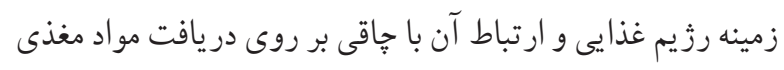

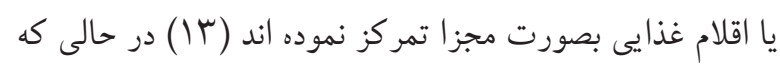

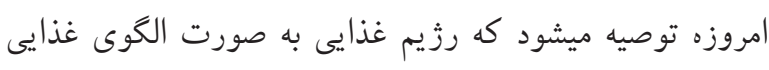

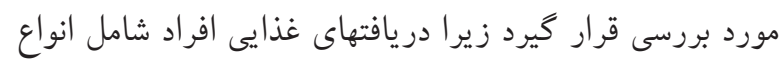

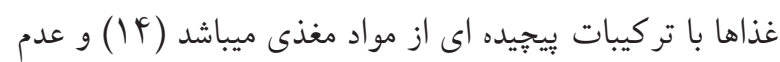
اكتشاف تمام تركيبات غذايى و تداخل بين مواد مغذى، موجب

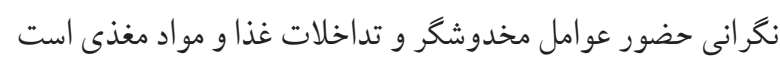

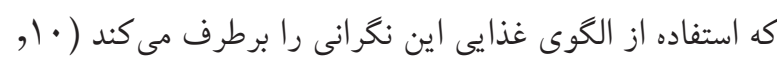

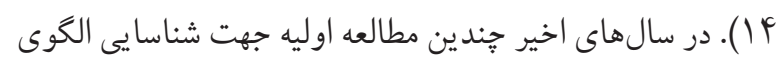
غذايى و بررسى رابطه آن با جاقى بزر گسالان ساكن شهر تهران

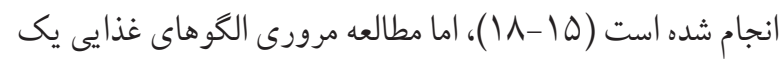
جامعه همكن مانند جامعه بزركسال شهر تهران انجام نشده است.

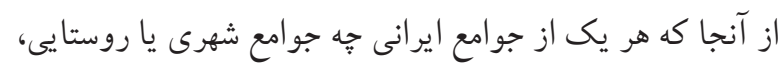

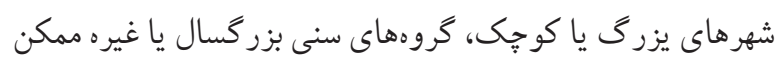

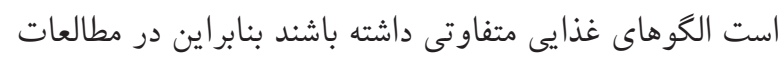

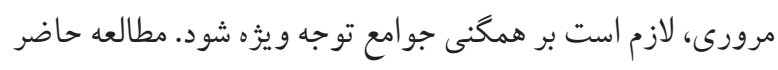

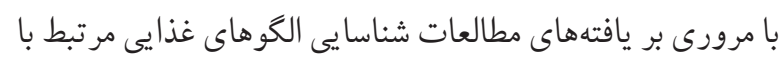

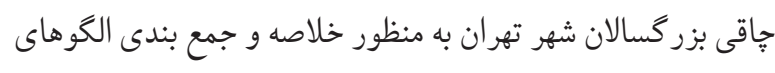

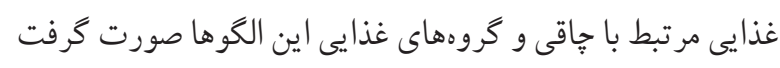

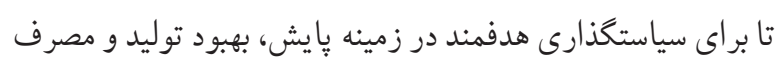
اقلام غذايى اشاره شده در يافتهاى مطالعه، بكار كرفته شود.

مو اد و روشها اين مطالعه از نوع مروردامنه اي است كه در خارجوب روش ينج مرحله

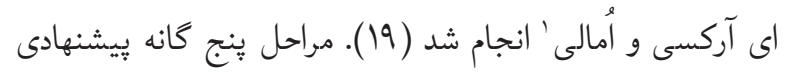

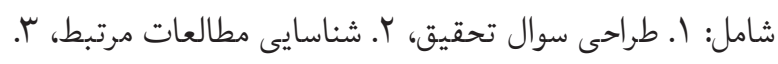

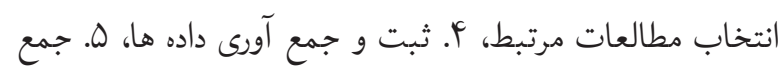

اضافه وزن و جاقى در بسيارى از كشورهاى توسعه يافته و در حال

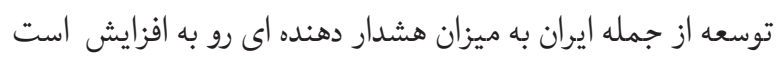

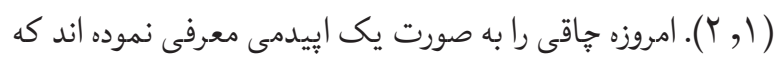
دلايل آن هنوز به درستى شناخته نشده است. در سطح فردى به نظر مىرسد كه تركيبى از دريافت انرزى غذايى بيش از حد مورد نياز

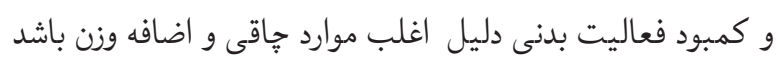

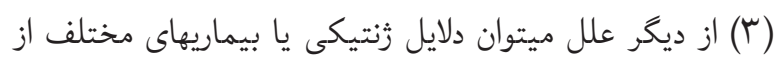

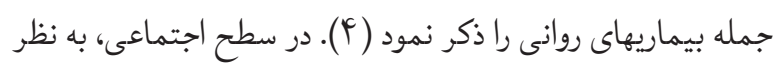

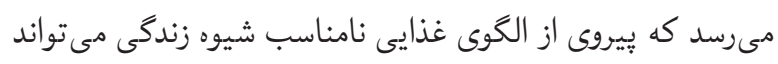
دليل افزايش نرخ جاقى و اضافه وزن باشد (ه). ارتباط رزيم غذايى با محيط عرضه مواد غذايى در مطالعات متعدد مشاهده شده است (9). عرضه مواد غذايى سالم، رزيم غذايى سالم را در دسترس مشتر يان قرار مىدهد و در انتخاب بهتر كمك مى كند

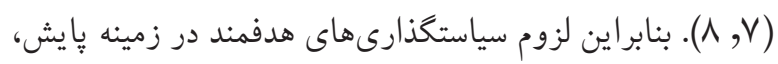
توليد و مصرف گروههاى غذايى خاص مىبايستى از اولويتهاى

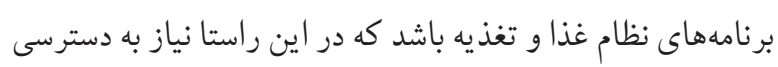
اطلاعات الكوهاى رايج غذايى مىباشد. نئ.

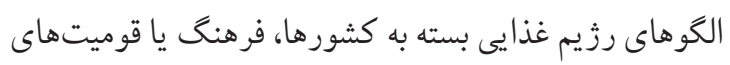
مختلف متفاوت است (9). تفاوت فرهنكى، اعتبار بيرونى و كاربرد يافته مطالعات الكوهاى غذايى را محدود مي كند. با توجه به اينكه الكوى غذايى بازتاب رفتارهاى غذايى است و ميتواند جزئيات بيشترى در مورد اتيولوزى غذايى بيماريهاى مزمن فراهم نمايد

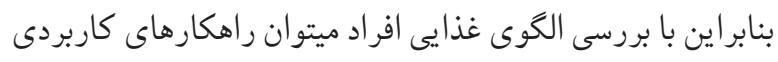

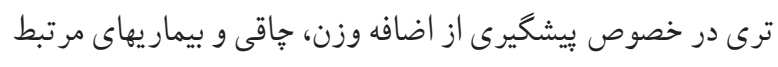

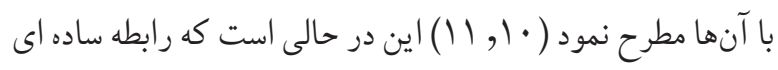

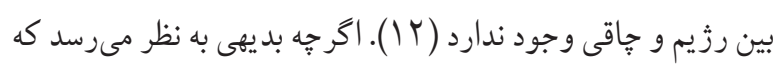

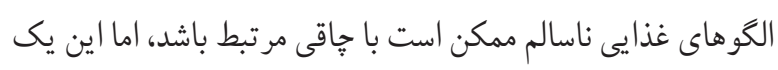

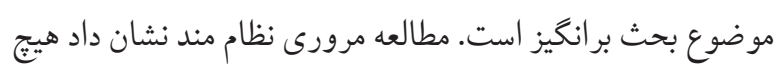

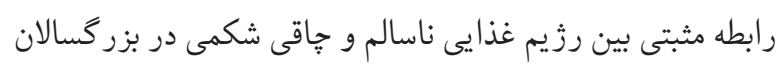

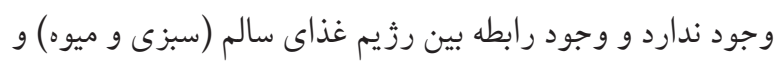


تكرارى، فرآيند غربالكرى با بررسى عنوان و جکكيده مقاله ها انجام شد. سيس متن كامل مقالات توسط دو فرد بطور جداكانه بر اساس معيارهاى

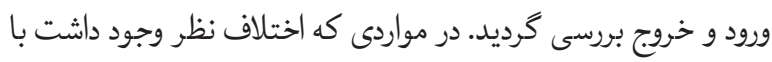
تبادل نظر برطرف مىشد. پِايان نامه خاى غربال شده الى كه نتايج آن

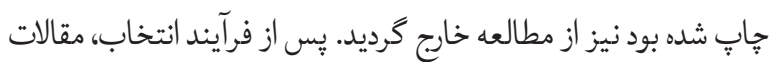
اوليه و بايان نامه ها وارد مطالعه مرور دامنه اى حاضر شد. معيارهاى ورود عبارت بود از: مطالعات انجام شده در بازه

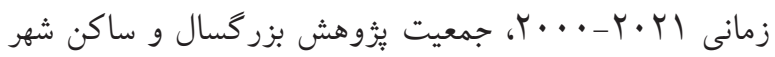

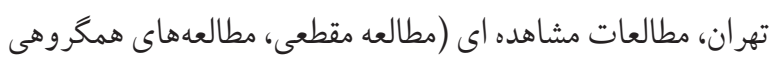

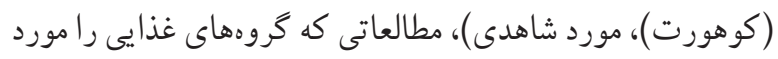

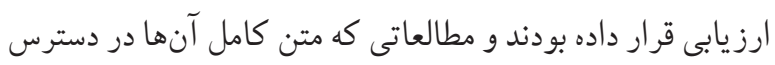
بود. معيارهاى خروج عبارت بود از: جمعيت يزوهش در گروهنهاى

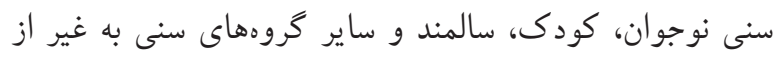
بزر گسال و جمعيت ساكن مكانى به غير از شهر تهران، مطالعه

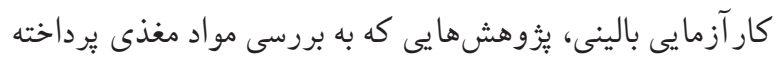

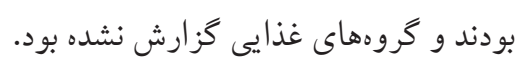
ثبت و جمع آورى داده ها در اين مرحله فرم استخراج داده ها طراحى شد. دو محقق به طور

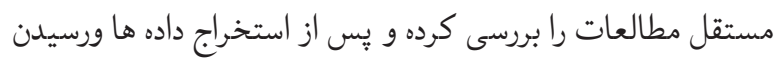
به اجماع نظر، آنها را در فرم استخراج داده ها ثبت ميىنمودند.

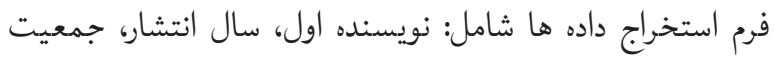

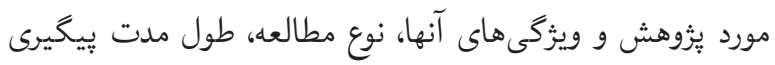

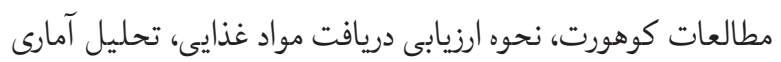

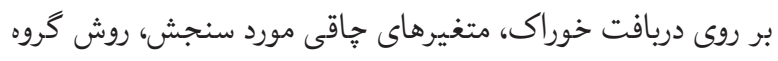
بندى اقلام غذايى، يافتهاى مربوط به شناسايى الكوهاى غذايى، كروههاى غذايى هر يك از الخوهاى غذايى، اقلام غذايى هريك از كروههاى غذايى و يافتهاى ارتباط الكوهاى غذايى با متغيرهاى جاقى بود. كيفيت روش شناسى با استفاده از مقياس نيوكاسل اتاوا

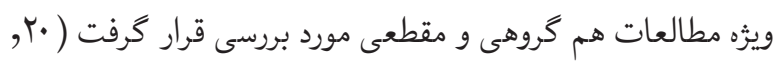

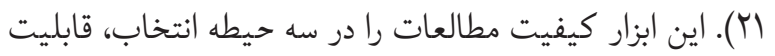

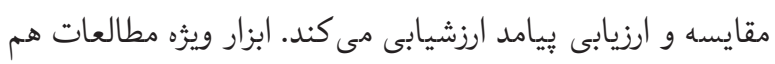

بندى، خلاصه سازى و كزارش يافته ها است. اين مطالعه با هدف

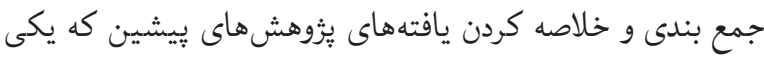

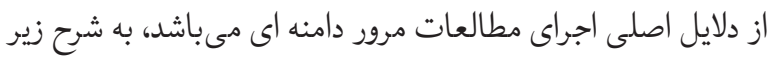
طراحى و اجرا شد.

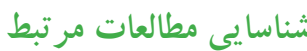
در مطالعه حاضر، كليه مقالات فارسى و انخليسى زبان مندرج

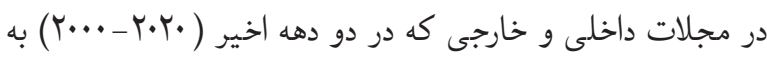

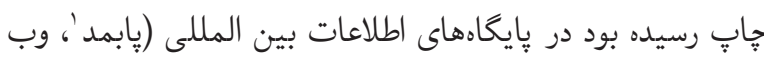

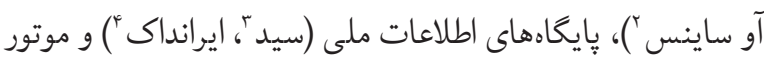

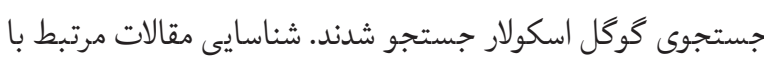

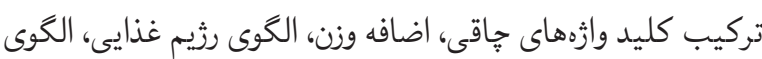

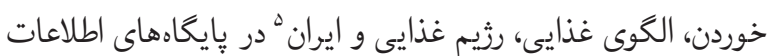
بين المللى و پايكاههاى اطلاعات ملى انجام شد.

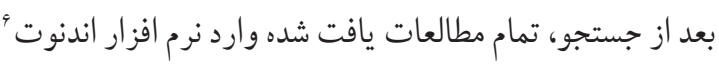
كرديد. جستجوى دستى بايان نامههاى كارشناسى ارشد و دكتراى

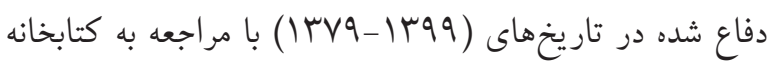
دانشكدهاى علوم تغذيه شهيد بهشتى، تهران، ايران و كزارشات نهايى طرحهاى تحقيقاتى مصوب با مراجعه به انستيتو تحقيقات

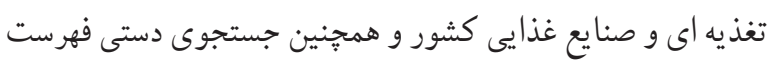

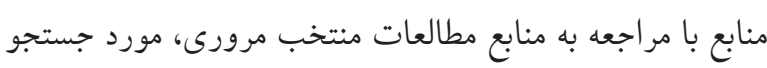

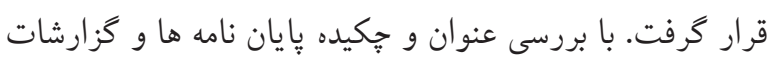

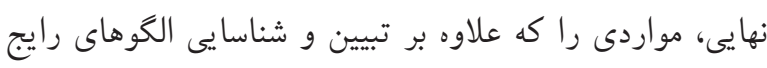

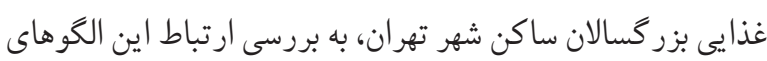

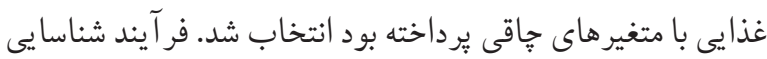

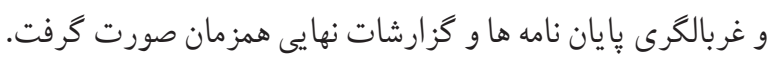

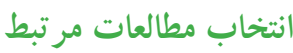
يس از ورود مقالات جستجو شده به نرم افزار اندنوت و خارج نمودن موارد

1. PubMed

2. Web of Science

3. SID

4. Iran Doc

5. (Obesity OR overweight) AND («dietary pattern» OR «eating pattern» OR «food pattern» OR diet) AND Iran

6. EndNote 
كروهى حداكثر تا 9 امتياز و ابزار ويثه مطالعات مقطعى حداكثر طرح هاى مصوب، 9 مطالعه مربوط به پايان نامه و ا مطالعه مربوط

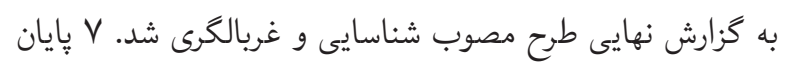
تا •l امتياز را در نظر كرفته است.

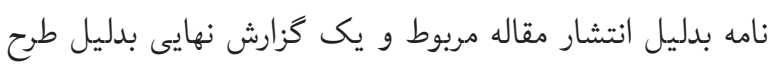

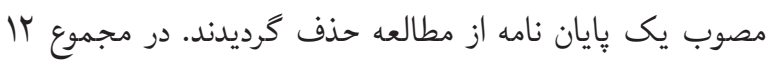
يافتنه

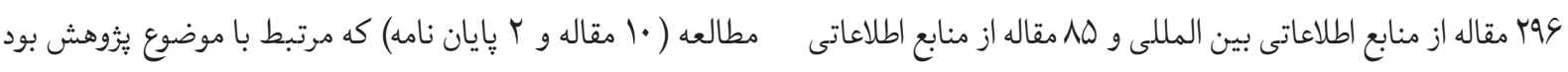

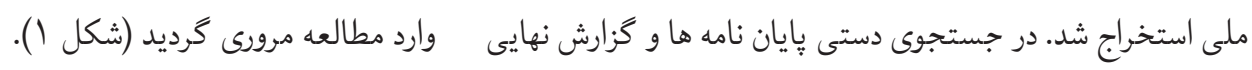

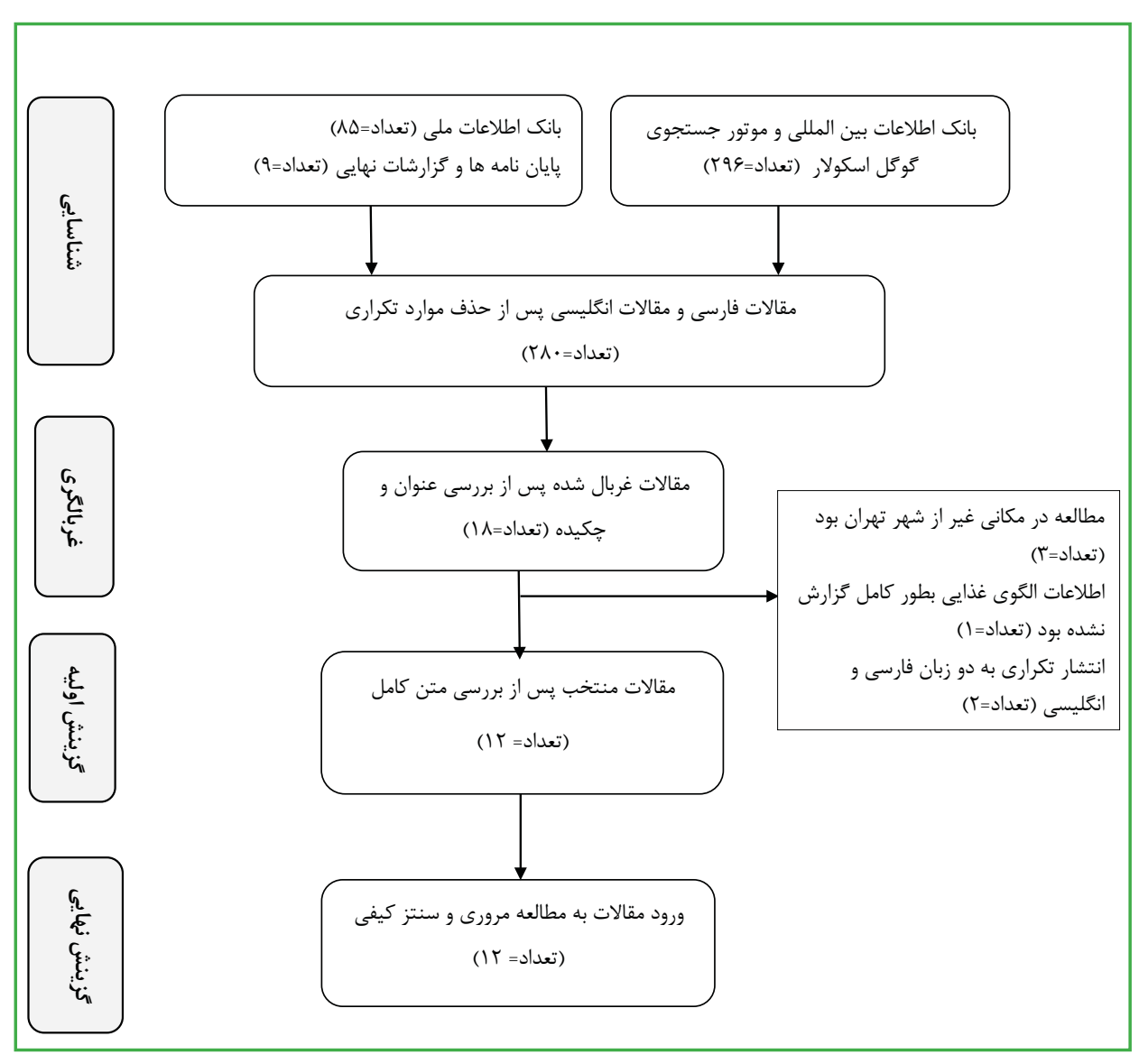

شكل ا. نحوه انتخاب و ورود مقالات به مطالعه

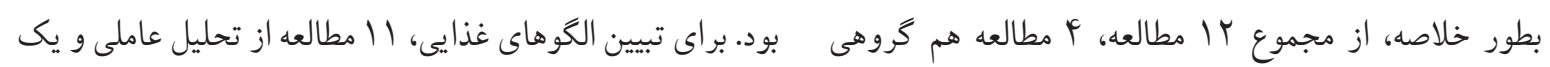

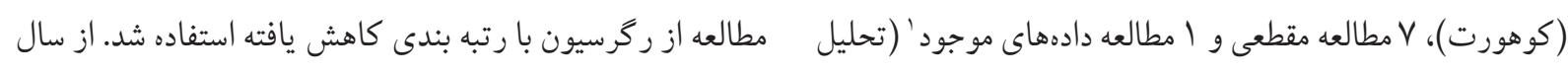

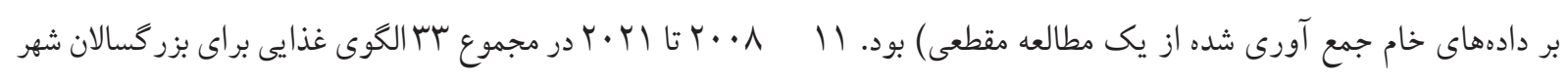

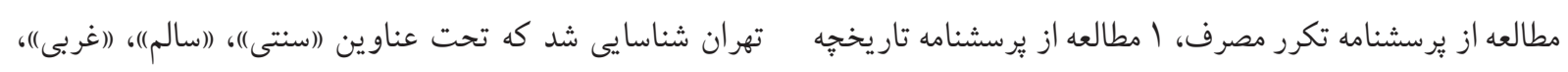

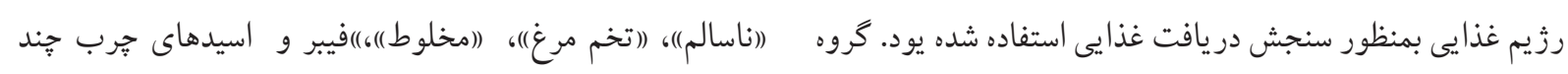

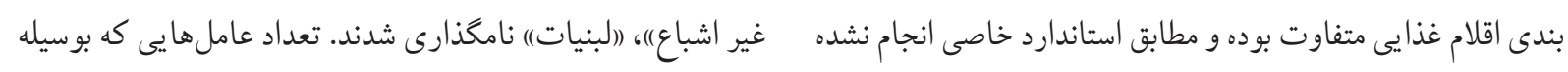

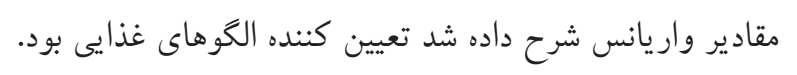


ناسالم با شاخصهاى آنترو يومتريك، زنتيك و خونى متفاوت بود.

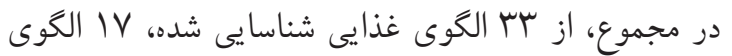

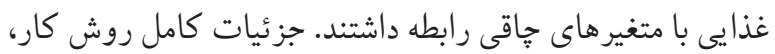

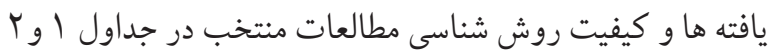

متغيرهاى جاقى شامل شاخصهاى آنترو يومتريك (تمام مطالعات)، متغيرهاى زنتيكى و يا خونى (سه مطالعه) بود. يافته ها نشان داد

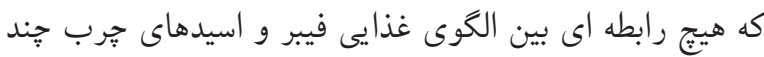

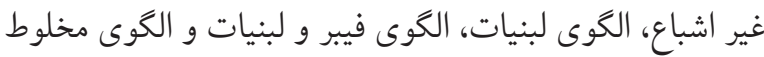

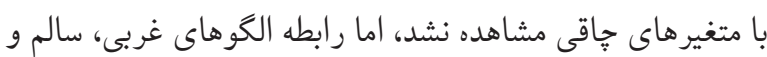

جدول ا. روش كار و خلاصه يافته هاى r 1 مطالعه منتخب

\begin{tabular}{|c|c|c|c|}
\hline يافتههاى رابطه الكوى غذايى با متغيرهاى جاقى & يافتههاى شناسايى الكوى غذايى & روش كار & نويسنده، سال \\
\hline 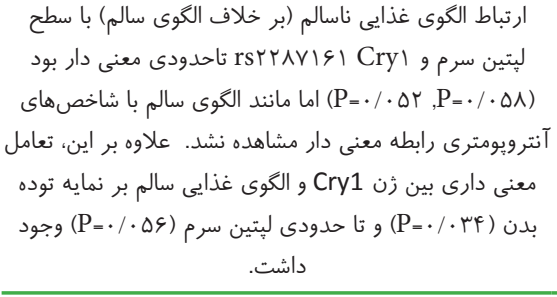 & 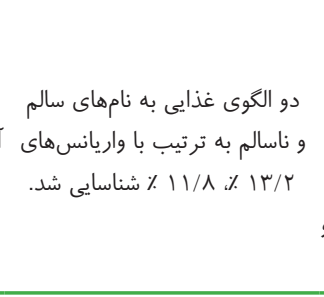 & 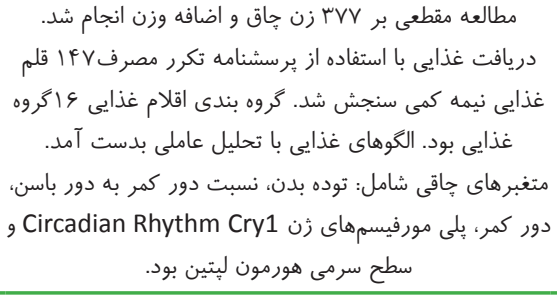 & 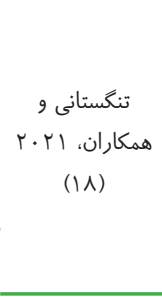 \\
\hline 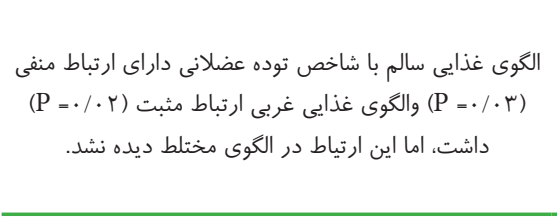 & 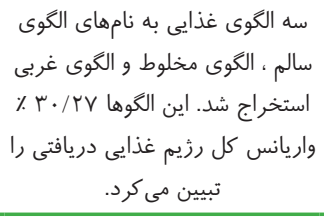 & 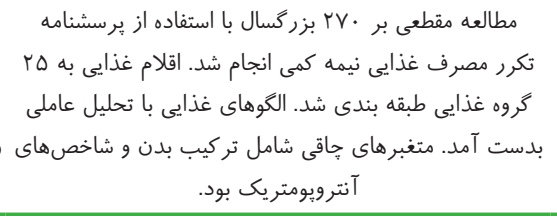 & 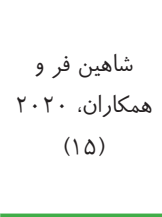 \\
\hline 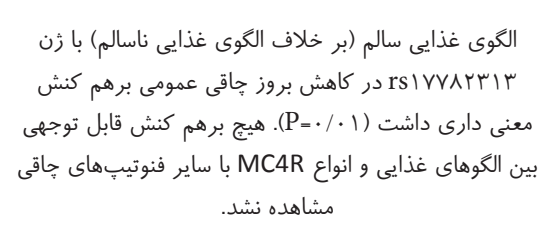 & 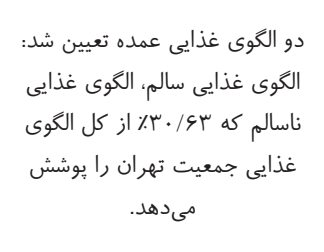 & 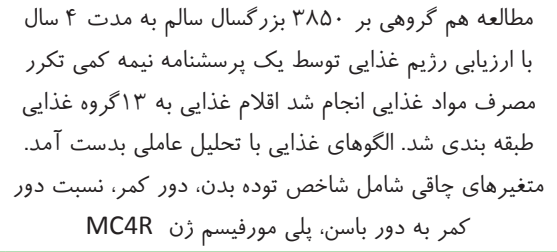 & 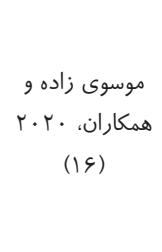 \\
\hline 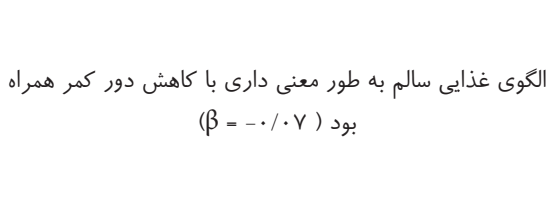 & 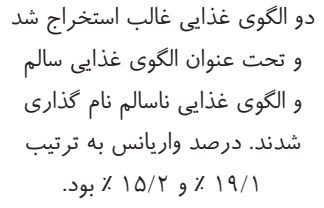 & 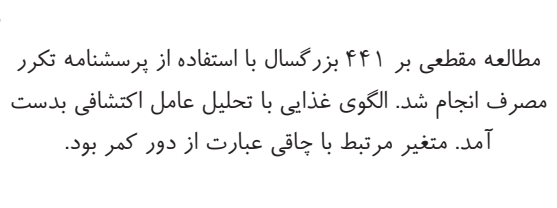 & 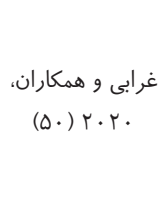 \\
\hline 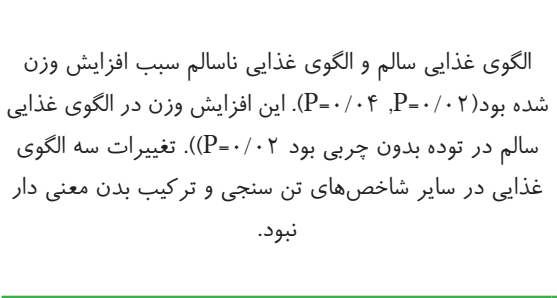 & 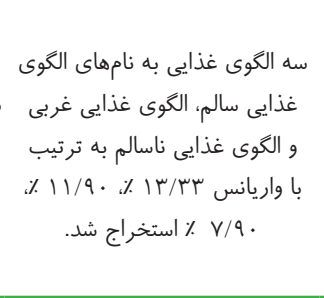 & 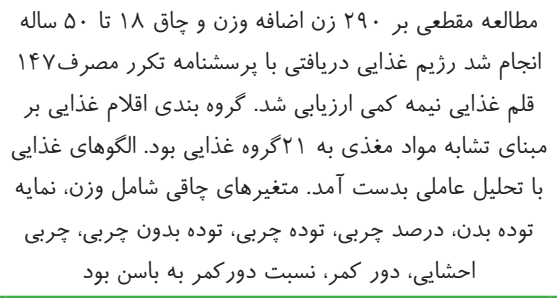 & 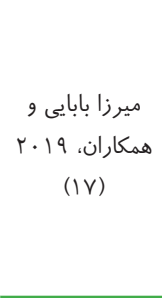 \\
\hline 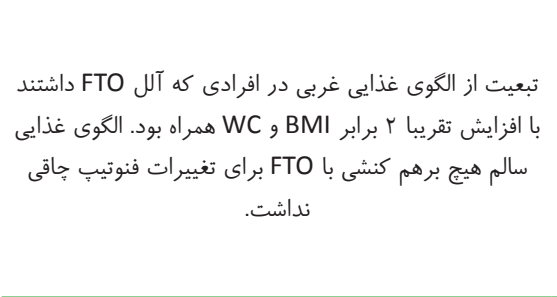 & دو الكوى غذايى سالم و غربى شناسايى شد. & 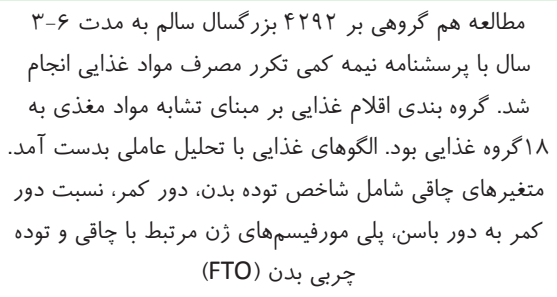 & 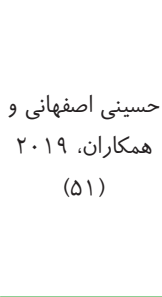 \\
\hline
\end{tabular}




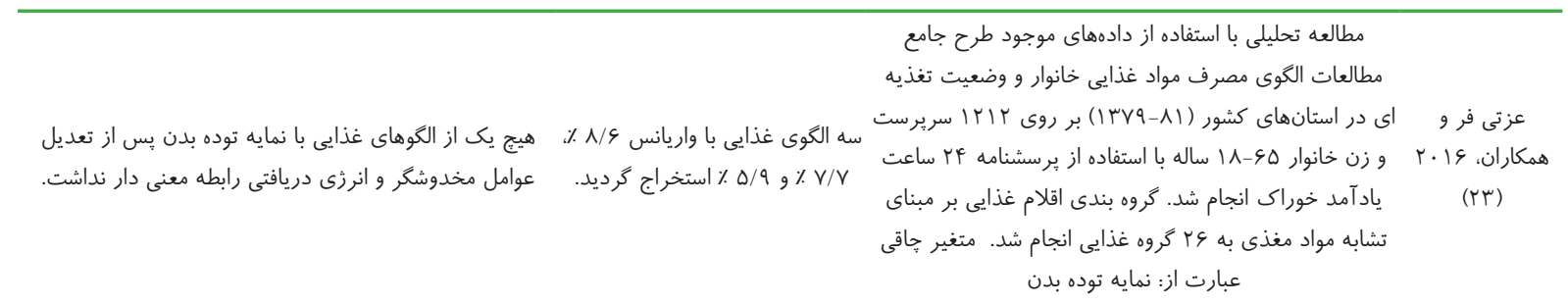

افرادى كه در بالاترين جار كى الكوى غذايى سالم قرار داشتند،

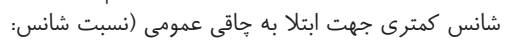

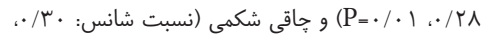

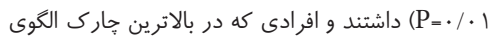

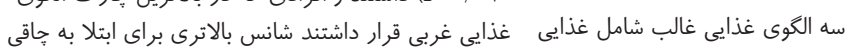

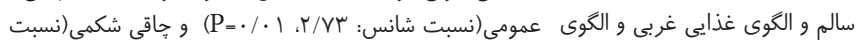

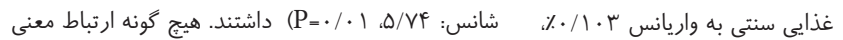

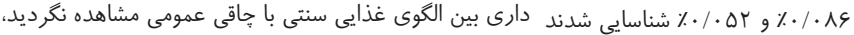

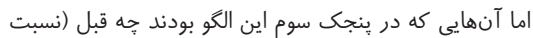

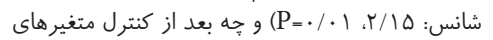

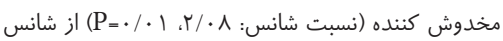

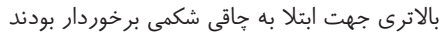

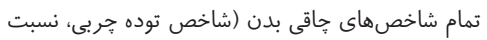

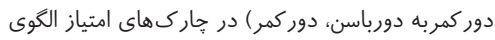

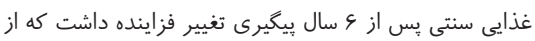

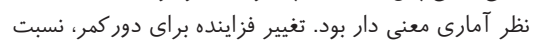

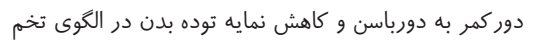

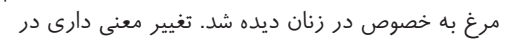

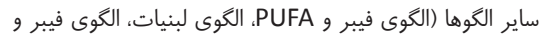

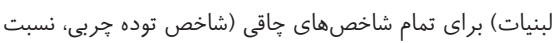
دور كمربه دورباسن، دور كمر ) وجود نداشت تونت

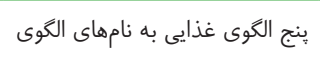

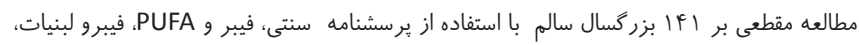

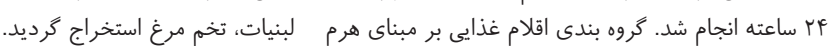

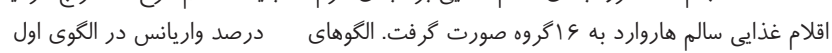

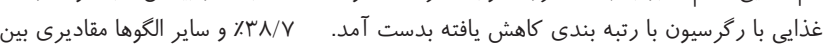

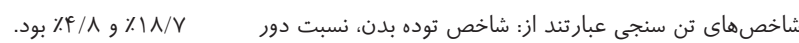
رويا شرافت كاظم

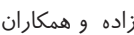
(rᄉ) r. r.

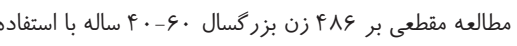

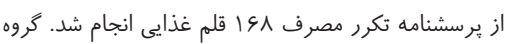

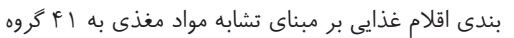

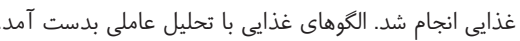

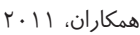

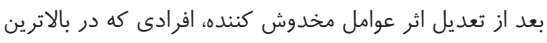

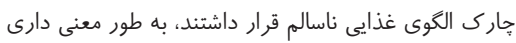

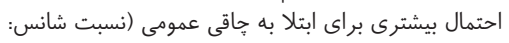

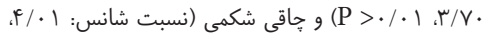

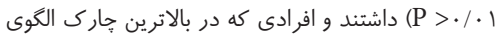

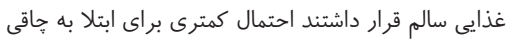
عمومى و جاقى شكمى داشتند.

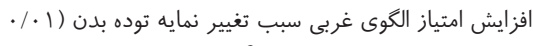

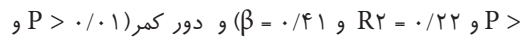

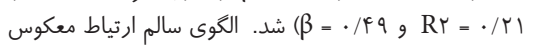

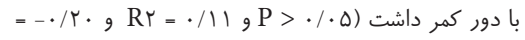

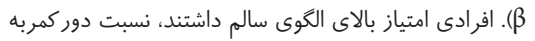

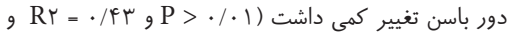

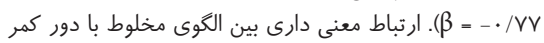
و شاخص توده بدن و نسبت دور كمر به دور يارئ ياسن ديده نشد.
سه الكو استخراج و الكوهاى غربى، سالم و مخلوط نام كذارى شدتد. درصد واريانس الكوها به ترتيب

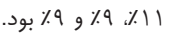

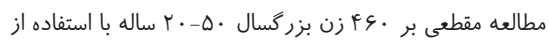

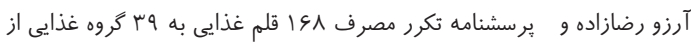

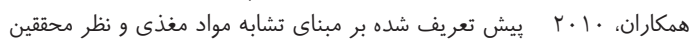

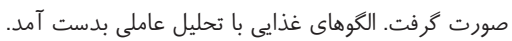

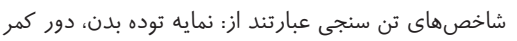

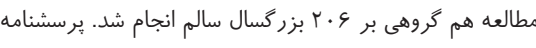

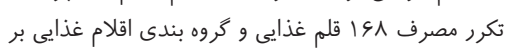

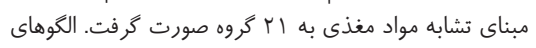

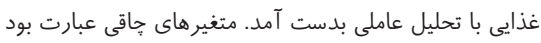
از: نمايه توده بدن، دور كمر، نسبت دور كمر به دور باسن باسن
فيروزه حسينى

اصفهانى 9

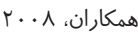

(هr)

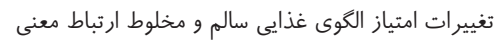

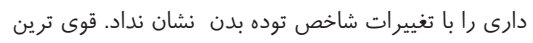

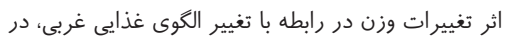

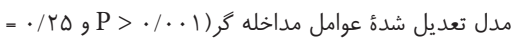

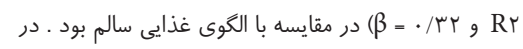

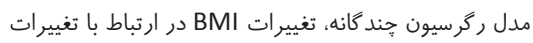

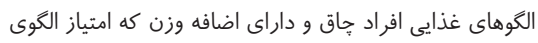

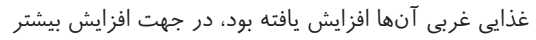

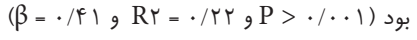

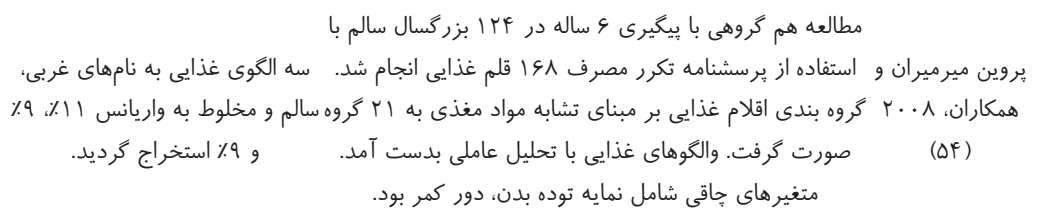


جدول r: كيفيت روش شناسى مقالات منتخب بر اساس مقياس نيوكاسل اتاوا

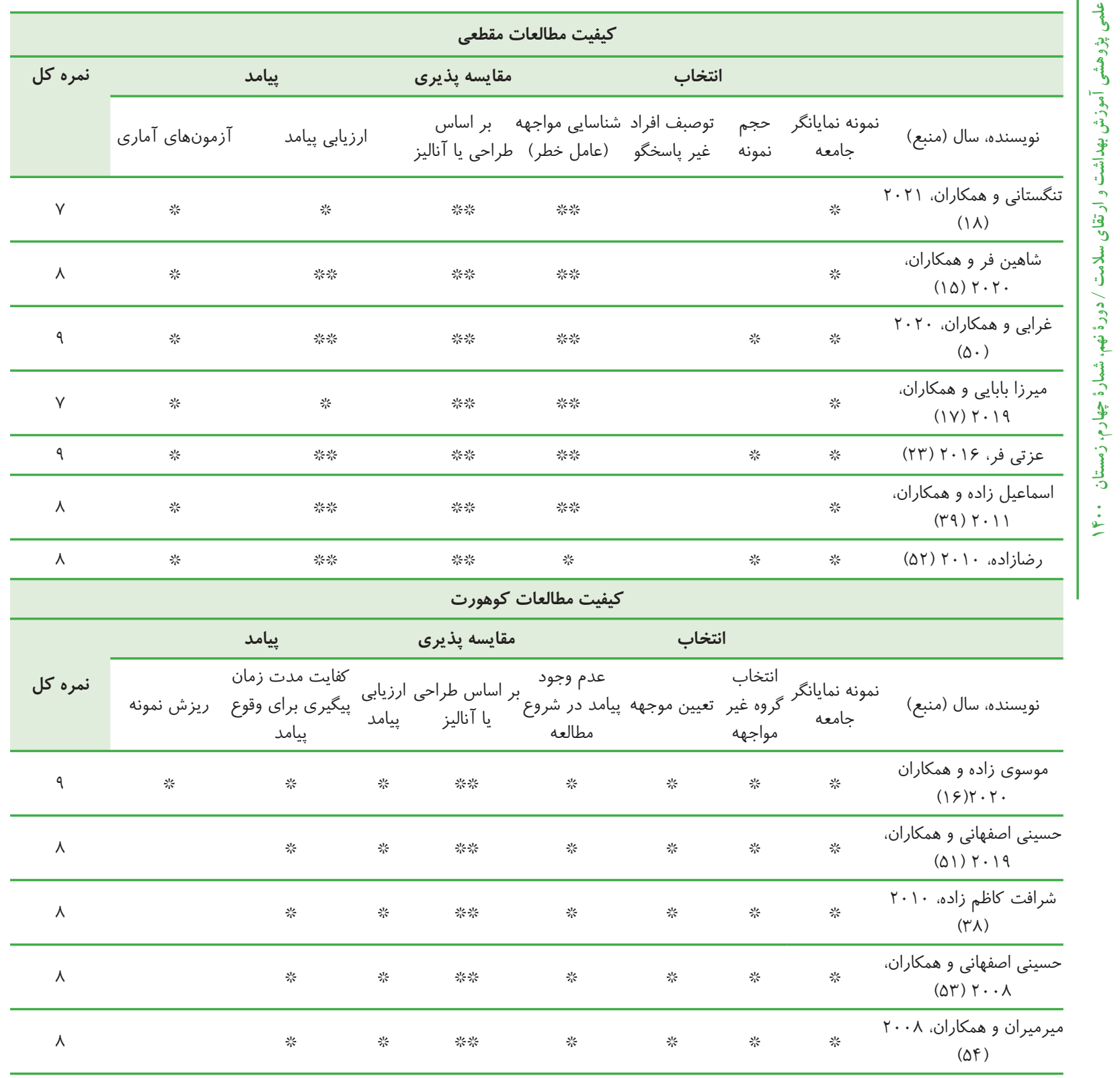

جدول بو ويز گى هاى الكوهاى غذايى مرتبط با متغيرهاى خاقى الخوى غذايى مطلوب محسوب شده است. بنابر اين در طى دو دهه

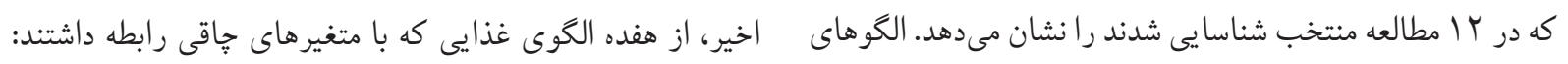

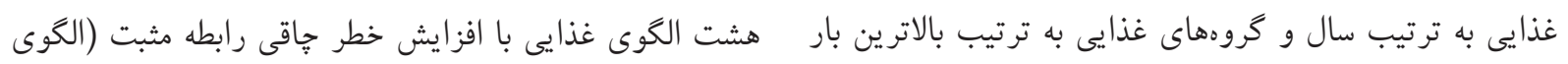

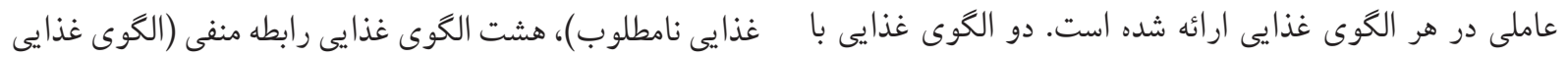

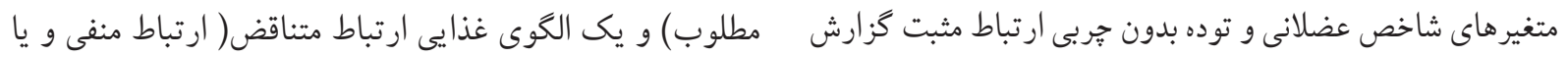

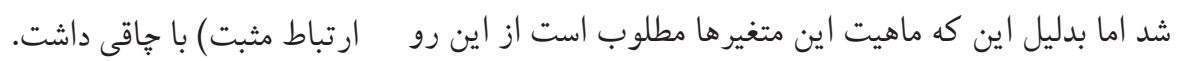


جدول سا. ويثزى هاى الخوهاى غذايى كه با متغير هاى خاقى رابطه معنى دار داشتند

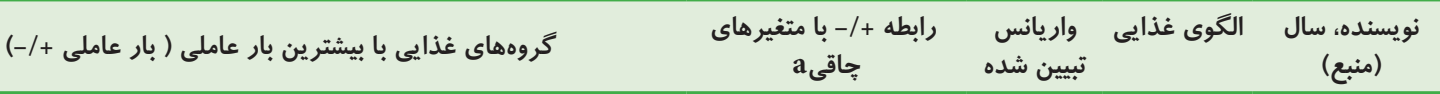

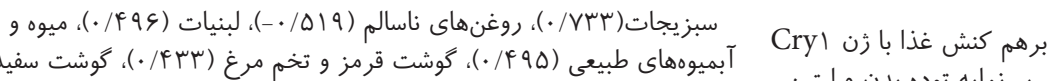

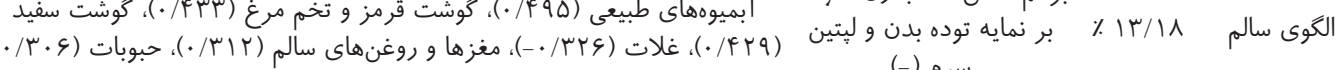
شكر /شيرينى /دسر (ب/ • •-)

سرم (-) تنكستانى و همكاران،

$(\mid \Lambda) r \cdot r \mid$

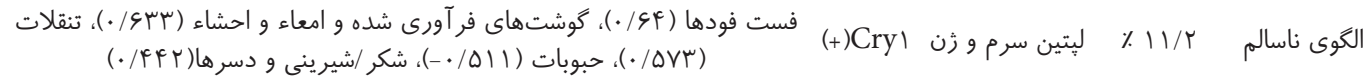

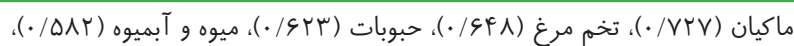

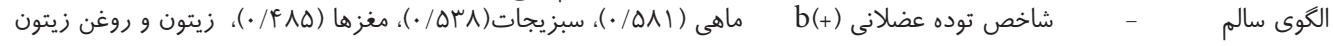
(. )

شاهين فر r.r.

(10)

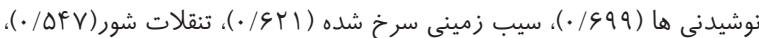

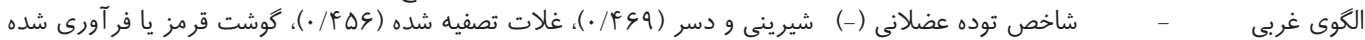

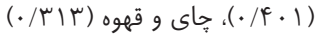

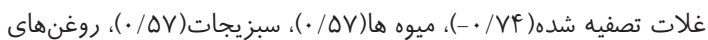

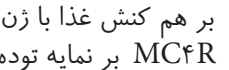

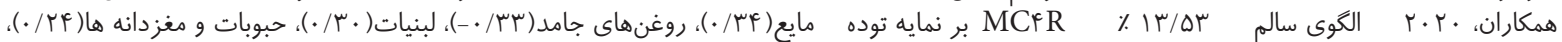

بدن (-) برن

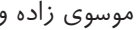

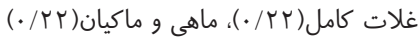

(14)

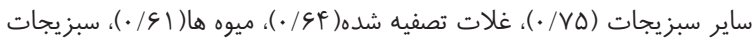

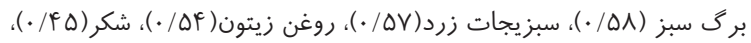

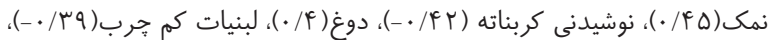

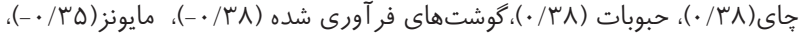

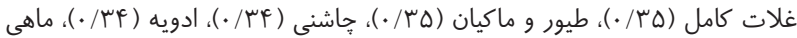

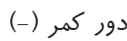

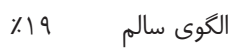

غرابى و همكاران،

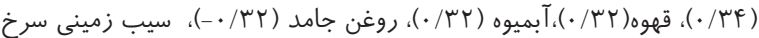

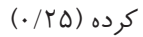

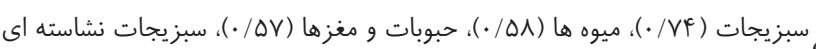

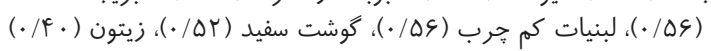

هيرزا بابايى 9

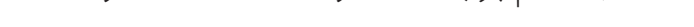

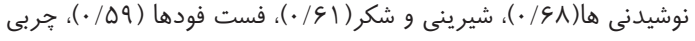

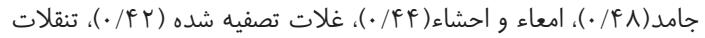

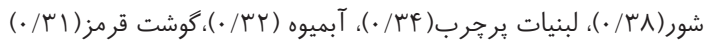

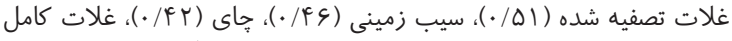

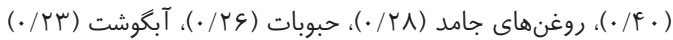

س س/ ٪ وزن و توده بدون جربى (+)

الخوى سالم

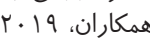

(IV)

بر هم كنش غذا با زن برن

برنمايه توده بدن و دور بند برن

$\% 1 \Delta / \vee$

حسينى اصفهانى 9

كمر (+) توده بلدن

(ه)

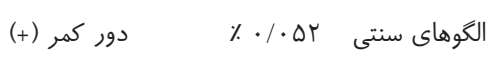

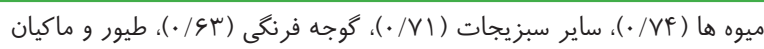

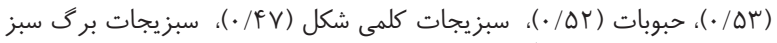

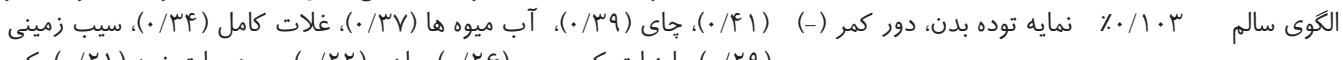

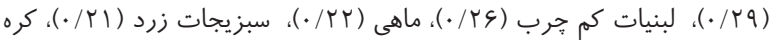

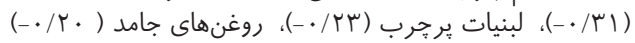

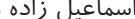

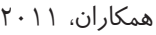

$($ (r)

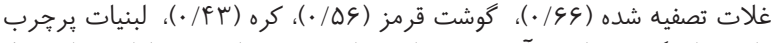

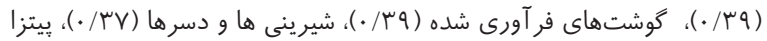

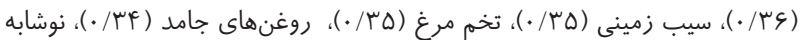

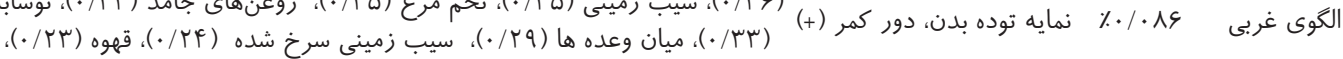

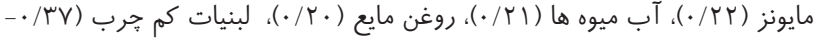

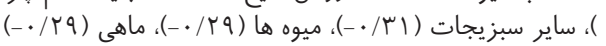

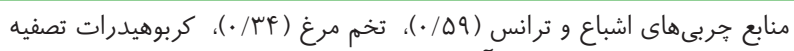

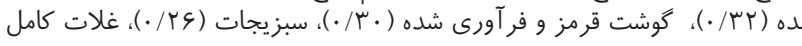

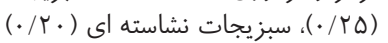

نمايه توده بدن، نسبت دور

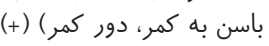

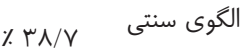

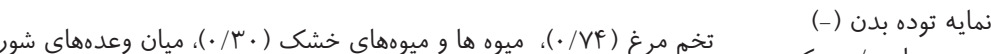

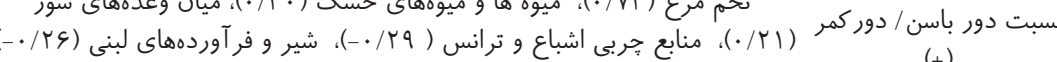

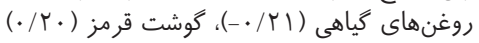

(+)

دور كمر)
رويا شرافت كاظم زاده و همكاران

(个人) r. 
ادامه جدول س. ويث گیىهاى الكَوهاى غذايى كه با متغير هاى خاقى رابطه معنى دار داشتند

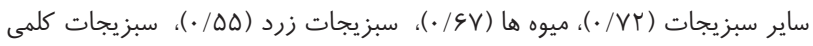

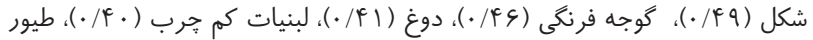

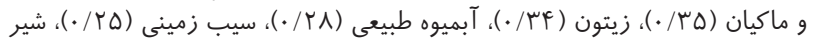
(./TF) (./TO)

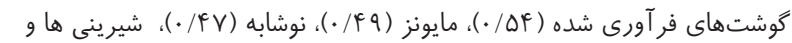

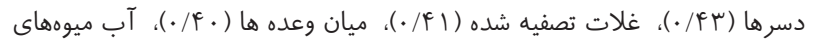

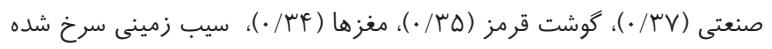
( ) ( سالم غذايى V/VV نمايه توده بدن، دور كمر (-)

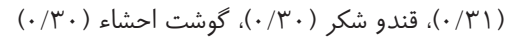

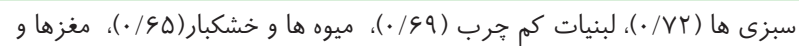

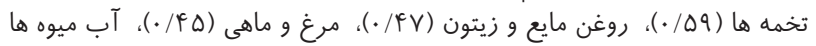

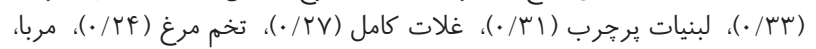

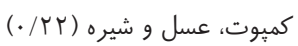

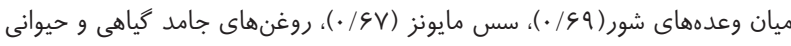

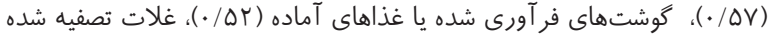

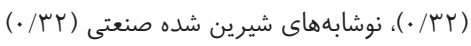

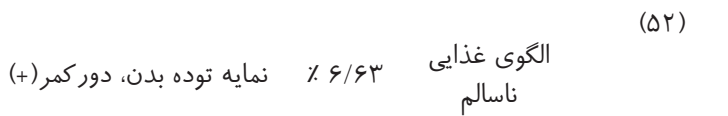
آرزو رضازاده و

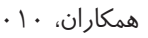

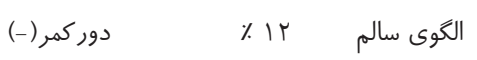

فيروزه حسينى اصفهانى و همكاران،

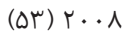

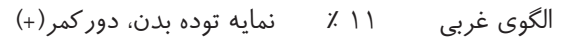

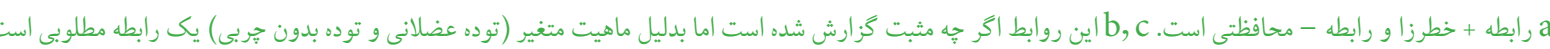

در همه هشت الكوهاى غذايى مطلوب بار مثبت شده بود، حبوبات ( به استثناء يك مورد در تمام الخوهاى مطلوب بارعاملى مثبت داشت)، غلات كامل ( به استثناء دو مورد كه بر الكوى غذايى سنتى بار مثبت داشت و در يك مورد، غلات كل (تصفيه شده و كامل) بار منفى داشت)، زيتون يا روغن زيتون (در ه مورد بار مثبت داشت) و ساير كروههاى غذايى مانند مغزها در بعضى از الخوهاى غذايى

$$
\text { مطلوب بارمثبت شده بود. }
$$

كروههاى غذايى كه در مواردى يا در الكوى غذايى مطلوب و يا در الكوى غذايى نامطلوب بار مثبت شده بود شامل: تخم مرغ، قهوه، لبنيات ( لبنيات كل، لبنيات كم جرب و لبنيات يرجرب) بود. كُوههاى غذايى كه طبقه بندى متفاوت داشتند شامل: غلات (غلات كل، تصفيه شده، كامل)، لبنيات (لبنيات كل، كم جرب، يرجرب)، مرغ و ماهى (كوشت سفيد، مرغ، ماهى)، سيزيجات (سبزيجات كل، سبزيجات برگ سبز، سبزيجات زرد، ساير سبزيجات، كو جه فرنكى، سبزيجات كلمى شكل، سبزيجات نشاسته ای، سيب زمينى)، شكر / شيرينى / دسر، كوشت قرمز / گوشت فر آورى شده/ امعاء و احشاء (توام يا جداكانه) بود. اقلام غذايى هر يك از گروههاى غذايى در جدول fا ارائه شده است.
كروههاى غذايى مشتر ك در هشت الگوى غذايى نامطلوب كه بار عاملى مثبت داشتند شامل: نوشابه شير ين شده صنعتى، شير ينى و دسرها، قندوشكر (به استثناء يك مورد كه مربا، كميوت، عسل و شيره انكور در الكوى غذايى مطلوب بار مثبت شده بود)، گوشت قرمز و گوشت فر آورى شده و امعاء و احشاء (به استثناء يك مورد كه گوشت قرمز و تخم مرغ در الخوى غذايى مطلوب بار مثبت شده بود)، جربى جامد و در يك مورد تحت نام جربى اشباع و ترانس( جهارمورد جربى جامد بر الحوى غذايى مطلوب بارمنفى شده بود)، غلات تصفيه شده (به استثناء يك مورد كه در الكوى غذايى مطلوب بار مثبت و در يك مورد بار منفى شده بود)، ميان وعدههاى شور و در مواردى تحت نام تنقلات شور( در دو مورد كه الخوى غذايى سنتى بود، بار نشده بود). ساير گروههاي غذايى مانند فست فود، مايونز، سيب زمينى سرخ شده، سيب زمينى و كره (يك مورد كه در الخوى غذايى مطلوب بار منفى داشت) در بعضى از الخوهاى غذايى نامطلوب بارمثبت شده بود. گروههاى غذايى مشتر ك در هشت الگوى غذايى مطلوب كه بار عاملى مثبت داشتند شامل: سبزيجات، ميوه ها، گوشت طيور و ماهى(ماهى در يك مورد از الخوى نامطلوب، بار منفى داشت) كه 
جدول عا: اقلام غذايى، كروههاى غذايى در الكَوهاى غذايى كه با متغير هاى جاقى رابطه معنى دار داشتند

\begin{tabular}{|c|c|c|c|}
\hline اقلام غذايى & 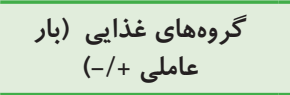 & 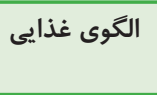 & نويسنده، سال \\
\hline 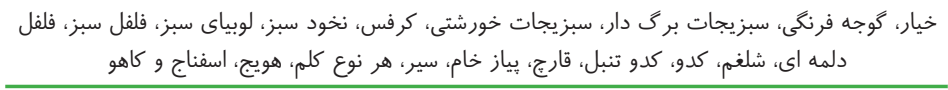 & سبزيجات (س اسM/.) & \multirow{9}{*}{ 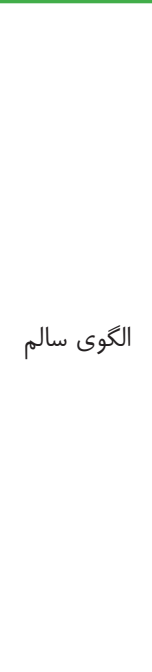 } & \multirow{13}{*}{ 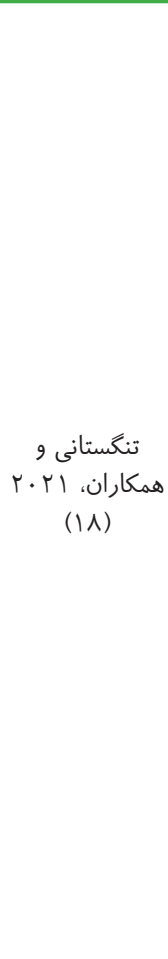 } \\
\hline روغن هيدروزنه، روغن نباتى، روغن حيوانى، سس مايونز، يِياز سرخ شده، بادمجان سرخ شده، كره و مار كارين & روغنهاى ناسالم (919/0 - -) & & \\
\hline شير، ماست، ينيرها، دوغ، كشك، خامه، ماست صاف شده، بستنى ها، شير كاكائو & 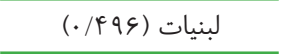 & & \\
\hline 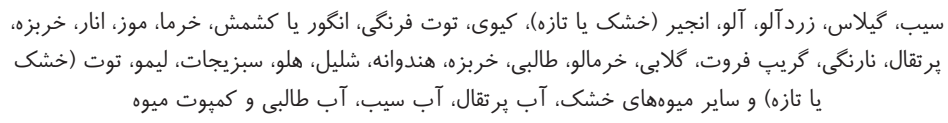 & 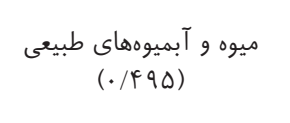 & & \\
\hline 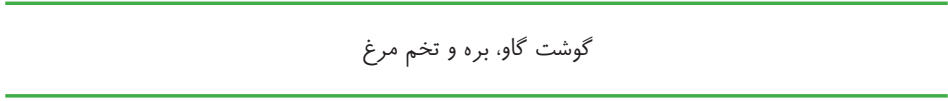 & 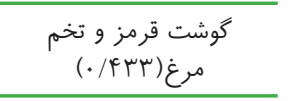 & & \\
\hline مرغ، ماهى و ماهى تن ماهى كنسرو شده & 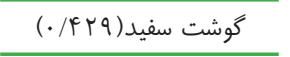 & & \\
\hline انواع نان، برنج، ماكارونى، رشته فرنكى، ورميشل، آرد گندم، جو، بلغور جو دوسر و ذرت & 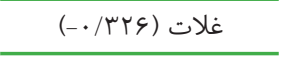 & & \\
\hline 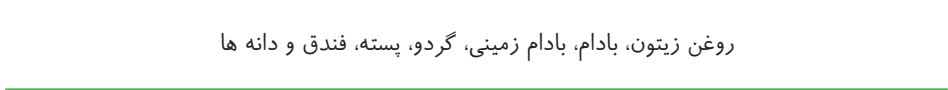 & 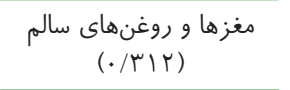 & & \\
\hline لوبيا، نخود فرنغى، عدس، ماش، نخود، لوبياى سويا، لوبيا & 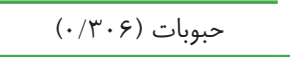 & & \\
\hline يِيتزا، سيب زمينى سرخ كرده و سوسيس و كالباس & 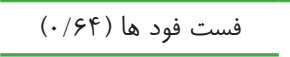 & \multirow{4}{*}{ 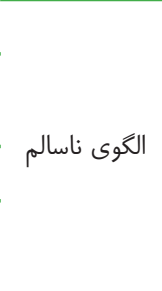 } & \\
\hline اندامهاى داخلى گوشت بره مانند جكر، قلب، كليه و غيره و گوشت هاى فر آورى شده مانند همبركر و هات & 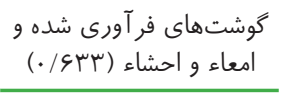 & & \\
\hline 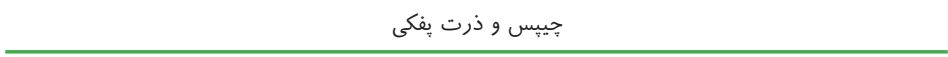 & 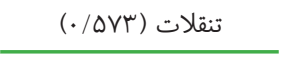 & & \\
\hline بيسكويت، كراكر، كيك، شكر، آب نبات، شكلات، عسل، نوشابه، آب ميوههاى تجارى، مربا و انواع شيرينى ها & شكر /شيرينى و دسرها & & \\
\hline جوجه & 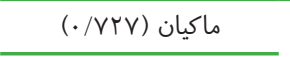 & \multirow{9}{*}{ 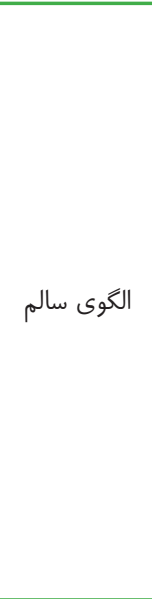 } & \multirow{16}{*}{ 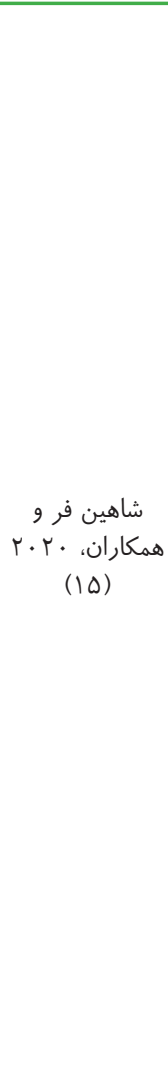 } \\
\hline انواع تخم مرغ & 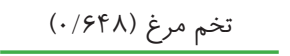 & & \\
\hline عدس، لِه، لوبيا، نخود، لوبيا، سويا و غيره & حبوبات (Arr/.) & & \\
\hline 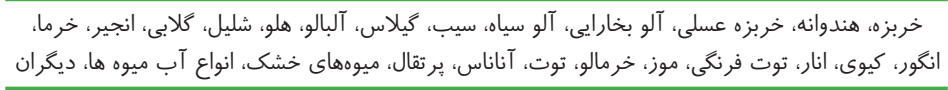 & 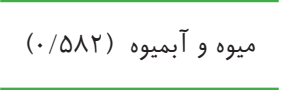 & & \\
\hline انواع ماهى & 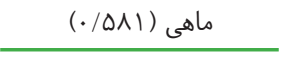 & & \\
\hline كل كلم، هويج، گوجه فرنكى و محصولات آن، اسفناج، كاهو، خيار، بادمجان، بياز، سبزى، لوبياى سبز، نخود & 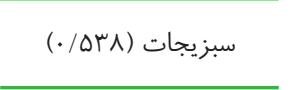 & & \\
\hline بادام، بادام زمينى، گردو، يسته، فندق، دانه ها و غيره & 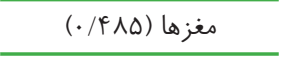 & & \\
\hline 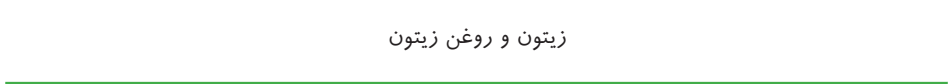 & 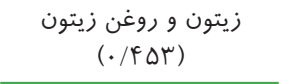 & & \\
\hline شير كم جرب، شير بدون جربى، ماست كم :جرب، هنير، كشك، دوغ و غيره & 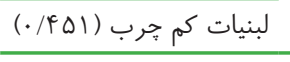 & & \\
\hline انواع نوشيدنى ها & 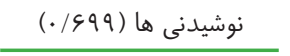 & \multirow{7}{*}{ 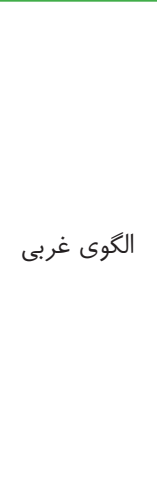 } & \\
\hline 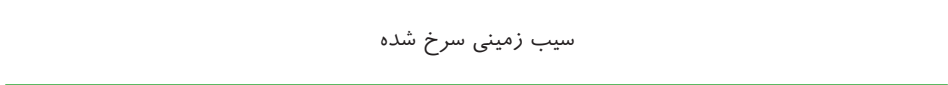 & سيب زمينى سرخ شده & & \\
\hline ذرت بفكى، انواع كراكر، جييس سيب زمينى و غيره & تنقلات شور (DFV/.) & & \\
\hline كلوجه، كيك، بيسكويت، كلوجه، انواع تارت، شكلات، عسل، مربا، حبههاى قند، شكر، آب نبات، حلوا ارده و & 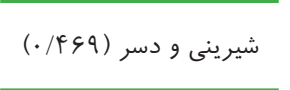 & & \\
\hline نان لواش، نان باگت، برنج، ماكارونى و غيره & غلات تصفيه شده (FهS/F) & & \\
\hline كوشت گاو و گوساله، گوشت بره، كوشت حرخ كرده، سوسيس، گوشت خوشمزه، همبر & كوشت قرمز يا فرآورى شده & & \\
\hline جاى و قهوه & جاى و قهوه (ساس//.) & & \\
\hline
\end{tabular}


ادامه جدول أ: اقلام غذايى، گروههاى غذايى در الحُوهاى غذايى كه با متغير هاى خاقى رابطه معنى دار داشتند

\begin{tabular}{|c|c|c|c|}
\hline \multirow{9}{*}{ اطلاعات در دسترس نيست } & غلات تصفيه شده (NFF •-) & \multirow{9}{*}{ الكوى سالم } & \multirow{9}{*}{ 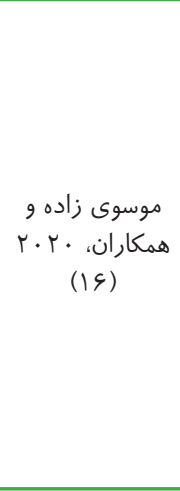 } \\
\hline & ميوه ها (DV/.) & & \\
\hline & سبزيجات ( سVV/.) & & \\
\hline & روغنهاى مايع (FF/F ) & & \\
\hline & 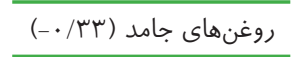 & & \\
\hline & لبنيات (·ر/.) & & \\
\hline & 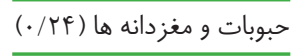 & & \\
\hline & 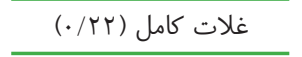 & & \\
\hline & 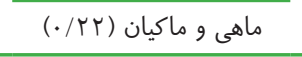 & & \\
\hline 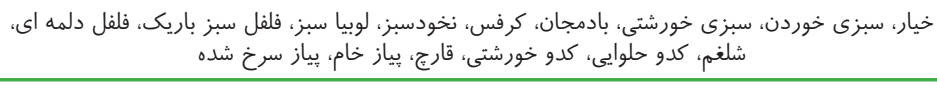 & 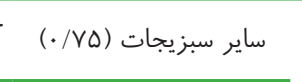 & \multirow{23}{*}{ 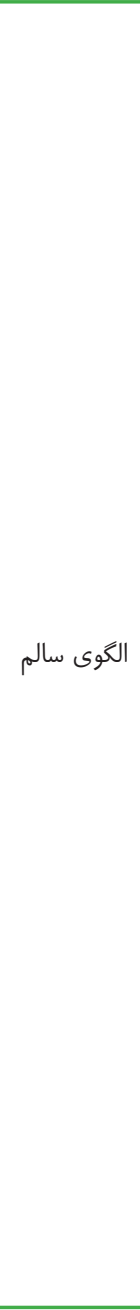 } & \multirow{23}{*}{ 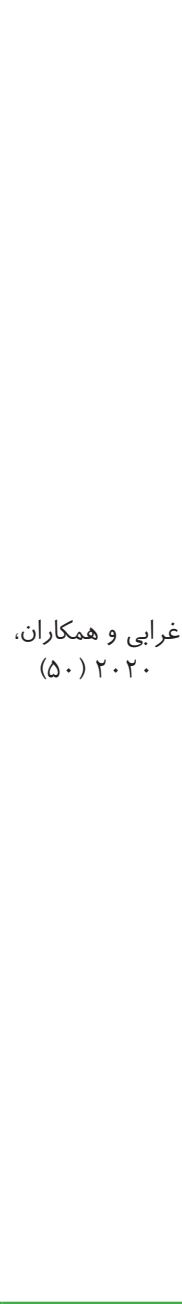 } \\
\hline 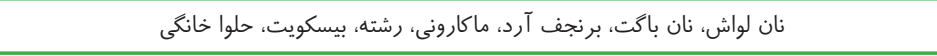 & 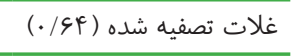 & & \\
\hline 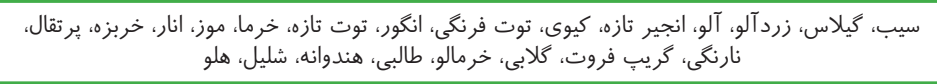 & ميوه ها (1/|.) & & \\
\hline اسفناج يخته، كاهو & 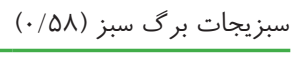 & & \\
\hline هويج خام، هويج بخته & سبزيجات زرد (DV/.) & & \\
\hline روغن زيتون & روغن زيتون (OF/•) & & \\
\hline شكر، قند، سوهان، كز، نبات، آبنبات، حلوا شكرى & 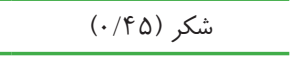 & & \\
\hline نمك & 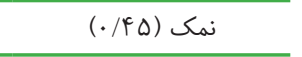 & & \\
\hline نوشابه & 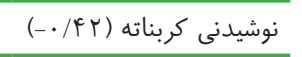 & & \\
\hline \multirow[t]{2}{*}{ شير كم جرب، ماست معمولى، ينير، كشك } & لبنيات كم خرب (qץ/.• & & \\
\hline & 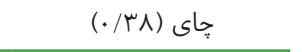 & & \\
\hline 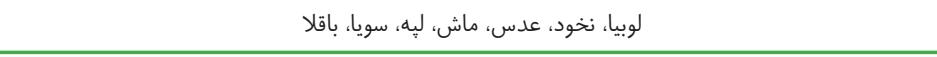 & 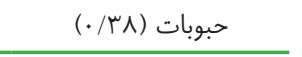 & & \\
\hline همبر گر، سوسيس، كالباس & كوشتهاىفر آورىشدهN/ / - ) & & \\
\hline س مس مايونز & مايونز (هـ/. - ) & & \\
\hline نان سنكک، نان بربرى، نان تافتون، جو و بلغور و ذرت & 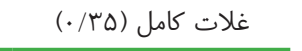 & & \\
\hline مرغ و جوجه & 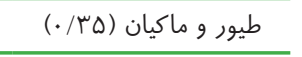 & & \\
\hline عسل، مربا & ) جاشنى (Tf/.) & & \\
\hline انواع ادويه ها & ادويه (TF/F/.) & & \\
\hline انواع ماهى، تن ماهى & 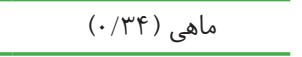 & & \\
\hline ق قهوه & قهوه ( & & \\
\hline آب يرتقال، آب سيب، آب طالبى & آبميوه (ץس/·) & & \\
\hline روغن نباتى جامد، روغن حيوانى & روغن جامد (r/T/•-) & & \\
\hline سيب زمينى سرخ شده & سيب زمينى سرخ كرده (ro/.) & & \\
\hline \multirow{7}{*}{ اطلاعات در دسترس نيست } & سبزيجات (JF) & \multirow{7}{*}{ الكوى سالم } & \multirow{7}{*}{ 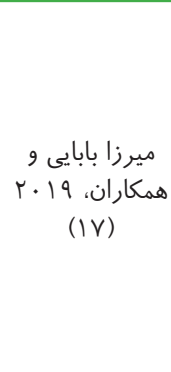 } \\
\hline & 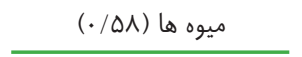 & & \\
\hline & حبوبات و مغزها (OV/ • ) & & \\
\hline & سبزيجات نشاسته اى(09/.) & & \\
\hline & لبنيات كم جرب (هو/.) & & \\
\hline & كوشت سفيد (Ur/.) & & \\
\hline & 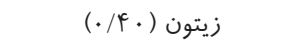 & & \\
\hline
\end{tabular}


ادامه جدول أ: اقلام غذايى، گَروههاى غذايى در الخُهاى غذايى كه با متغير هاى خاقى رابطه معنى دار داشتند

\begin{tabular}{|c|c|c|c|}
\hline \multirow{10}{*}{ اطلاعات در دسترس نيست } & نوشيدنى ها (\$N/.) & \multirow{10}{*}{ الكوى غربى } & \multirow{10}{*}{ 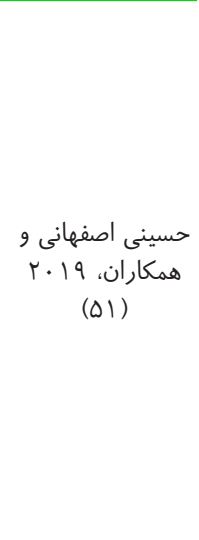 } \\
\hline & شيرينى و شكر (1)/.) & & \\
\hline & فست فودها (ه9/.) & & \\
\hline & جربى جامد (FA/.) & & \\
\hline & امعاء و احشاء (FF/.) & & \\
\hline & غلات تصفيه شده (r (F/.) & & \\
\hline & 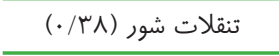 & & \\
\hline & لبنيات رِرجرب (FF/Ff) & & \\
\hline & آبميوه ( (Tس/.) & & \\
\hline & گوشت قرمز (اسّ/.) & & \\
\hline
\end{tabular}

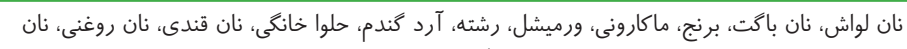

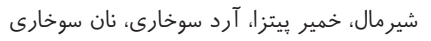

غلات تصفيه شده (01/01·)

\begin{tabular}{|c|c|}
\hline 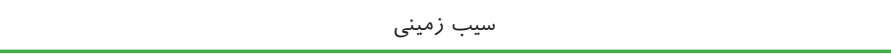 & سيب زمينى (4\&/.) \\
\hline جاى & 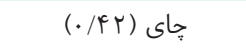 \\
\hline نان بربرى، نان سنكگ، نان تافتون، نان تست، جو پخته، جوانه كندم، بلغور، نان جو، سمنو، ذرت بو داده & غلات كامل (•/^.^) \\
\hline روغن نباتى جامد، ييه، روغن حيوانى & 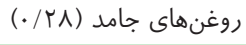 \\
\hline عدس، لوبيا، نخود، باقلا بخته، سويا، ماش، لِه، نخودجى & 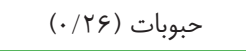 \\
\hline آبكوشت & آبكوشت (سr/.) \\
\hline
\end{tabular}

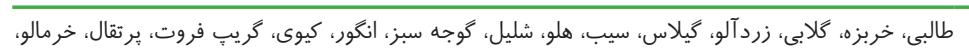

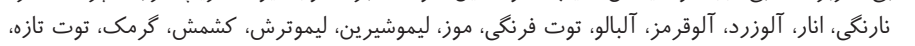

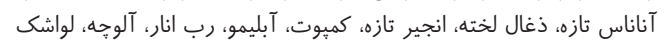

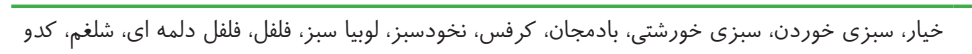

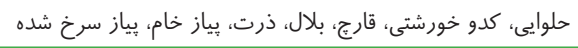

ميوه ها (VF)

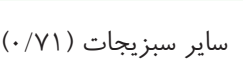

\begin{tabular}{|c|c|}
\hline گوجه فرنگى، سس قرمز (كوجه فرنگى، رب گوجه) & كوجه فرنغى( س / •) \\
\hline مرغ و جوجه & طيور و ماكيان (سه/•) \\
\hline عدس، لوبيا، نخود، باقلا پِخته، سويا، ماش، لٍه، نخودجى & حبوبات (DY/•) \\
\hline ل مر نوع كلم & سبزيجات كلمى شكل \\
\hline
\end{tabular}

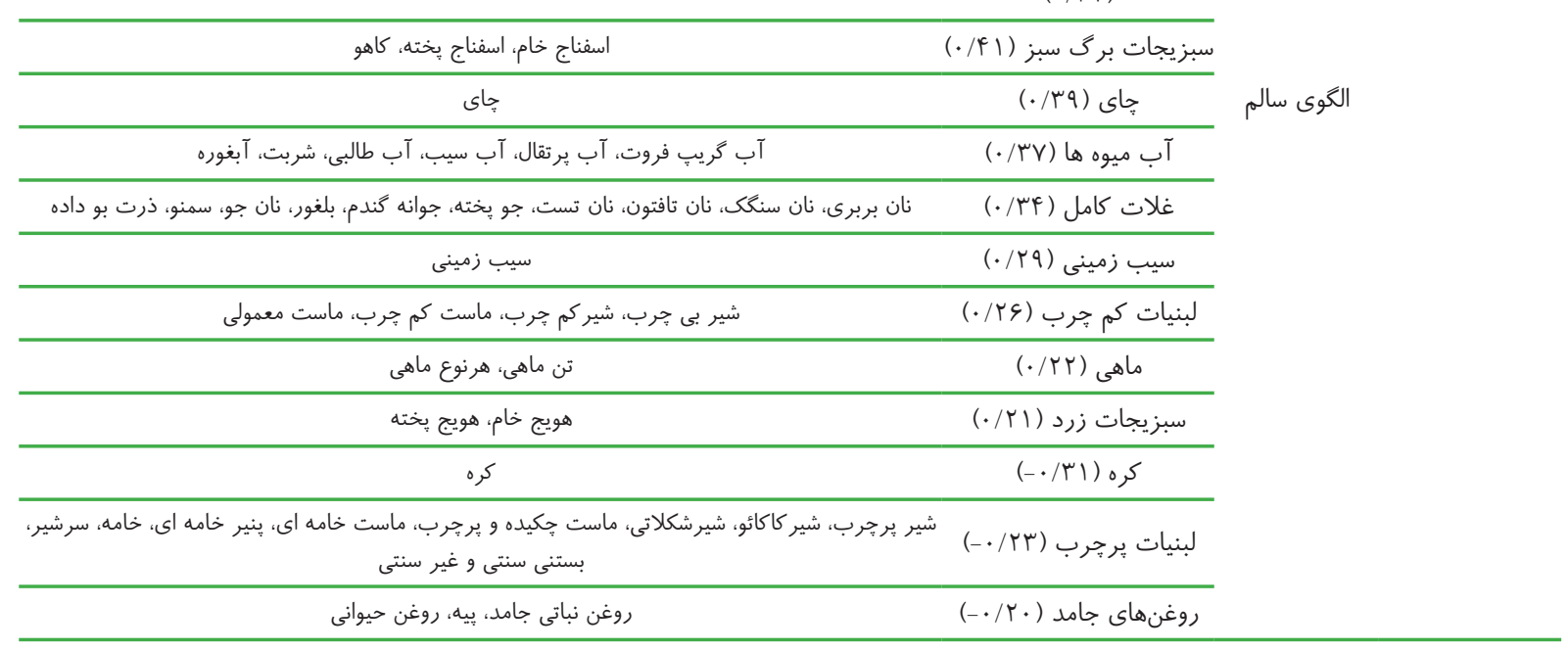

اسماعيل زاده و

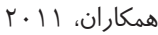

(rq) 
ادامه جدول أ: اقلام غذايى، گروههاى غذايى در الخُوهاى غذايى كه با متغير هاى حاقى رابطه معنى دار داشتند

\begin{tabular}{|c|c|c|c|}
\hline 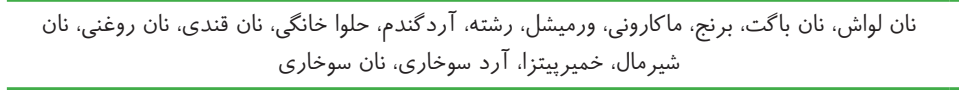 & غلات تصفيه شده (49/.) & \multirow{21}{*}{ 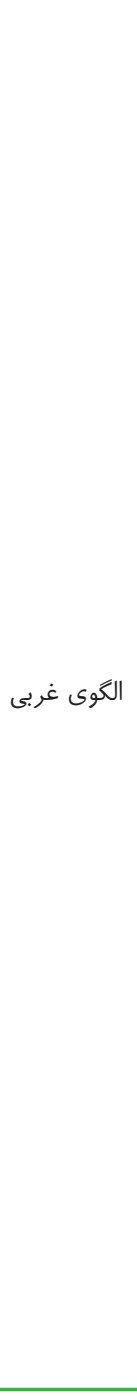 } & \multirow{28}{*}{ 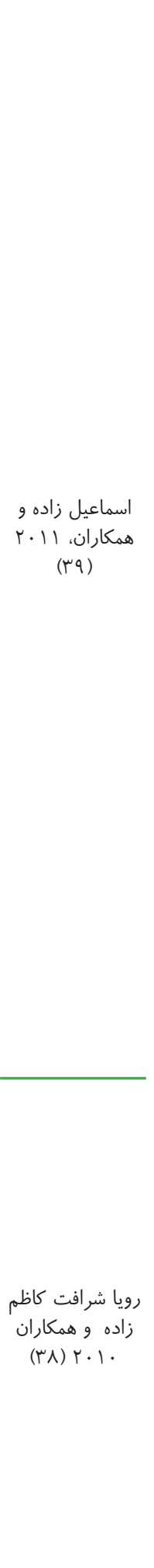 } \\
\hline 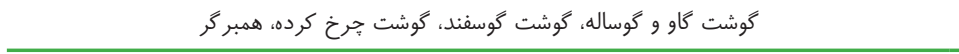 & 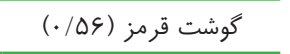 & & \\
\hline كر & 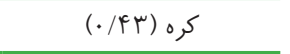 & & \\
\hline 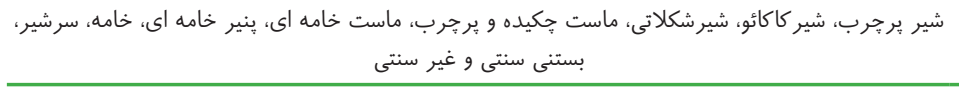 & لبنيات يرجرب (qه/.) & & \\
\hline سوسيس، كالباس & كوشتهاى فرآورى شده & & \\
\hline بير اشكى، كرم كارامل، شكلات، كبك يزدى، كيك خانكى، شيرينى خشك، شيرينى تر & شيرينى ها و دسرها (V「/.) & & \\
\hline ييتزا & 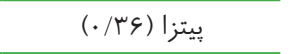 & & \\
\hline 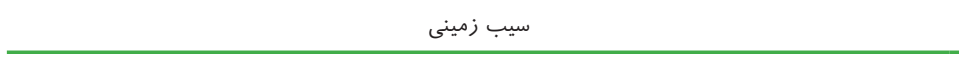 & 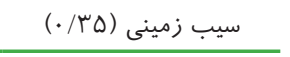 & & \\
\hline تخم مرغ & 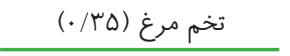 & & \\
\hline روغن نباتى جامد، بيه، روغن حيوانى & 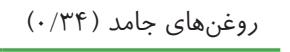 & & \\
\hline نوشابه، ماءالشعير & 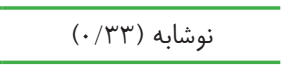 & & \\
\hline 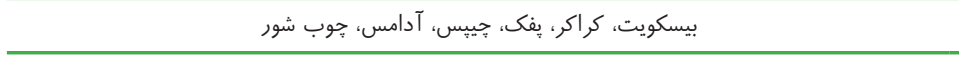 & 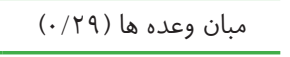 & & \\
\hline 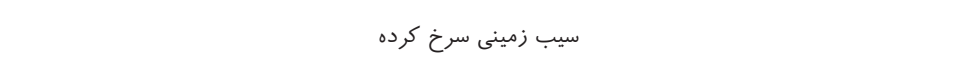 & سيب زمينى سرخ شده & & \\
\hline قهوه & 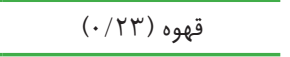 & & \\
\hline 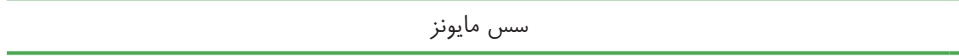 & 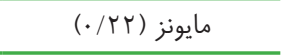 & & \\
\hline آب گريب فروت، آب برتقال، آب سيب، آب طالبى، شربت، آبغوره & 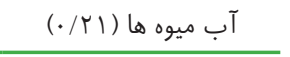 & & \\
\hline هر نوع روغن مايع (به غير از زيتون) & روغن مايع (·r/·) & & \\
\hline شير بى جرب، شير كم جرب، ماست كم جرب، ماست معمولى & لبنيات كم جرب (rV/ • - (-) & & \\
\hline 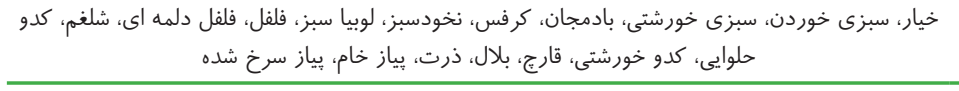 & 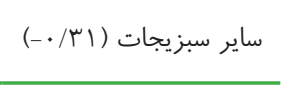 & & \\
\hline 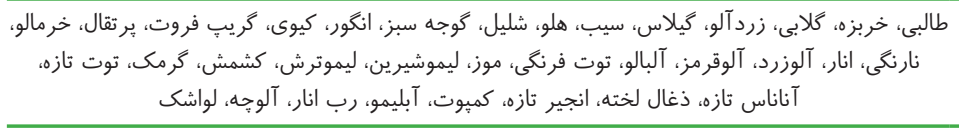 & 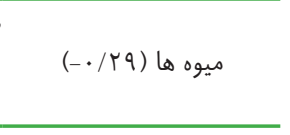 & & \\
\hline تن ماهى، هر نوع ماهى & 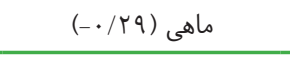 & & \\
\hline كره، ماركارين، دنبه، خامه و سرشير، روغن نباتى جامد، روغن حيوانى & 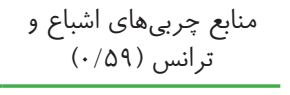 & \multirow{7}{*}{ 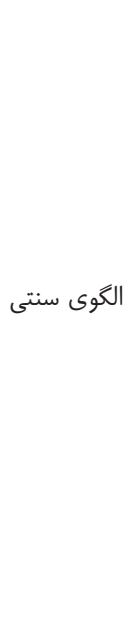 } & \\
\hline سفيده تخم مرغ، زرده تخم مرغ & 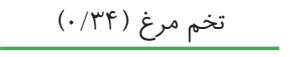 & & \\
\hline لواش، نان باكَ، تافتون، بربرى، نشاسته، آرد كندم، برنج، آرد برنج، ماكارونى، رشته، ورميشل، آرد سوخارى، & 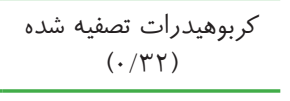 & & \\
\hline 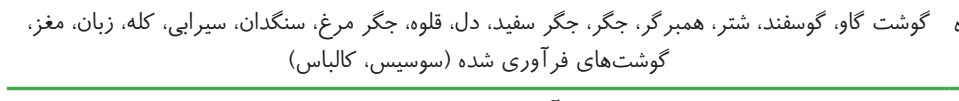 & 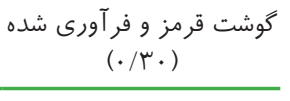 & & \\
\hline 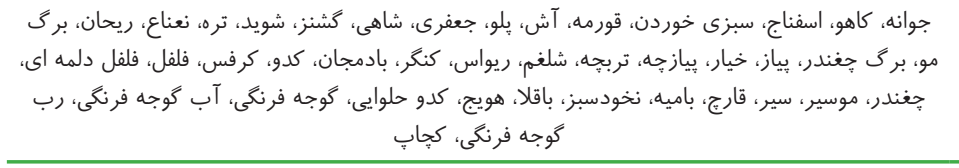 & 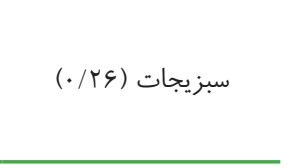 & & \\
\hline نان سنغك، نان جو، جو، گندم، بلغور، شاهدانه & 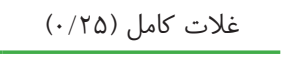 & & \\
\hline سيب زمينى، ذرت، باقلا زرد، كدو حلوايى & 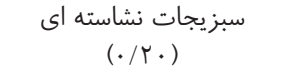 & & \\
\hline
\end{tabular}


ادامه جدول أ: اقلام غذايى، گَروههاى غذايى در الخوهاى غذايى كه با متغير هاى خاقى رابطه معنى دار داشتند

\begin{tabular}{|c|c|c|c|}
\hline سفيده تخم مرغ، زرده تخم مرغ & 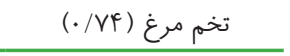 & \multirow{7}{*}{ 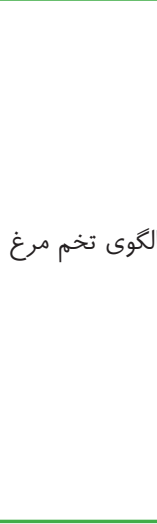 } & \multirow{7}{*}{ 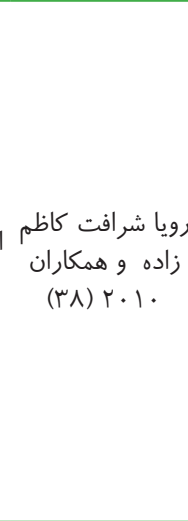 } \\
\hline 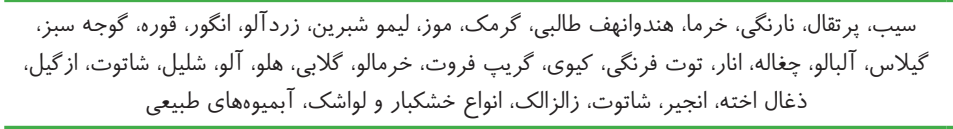 & 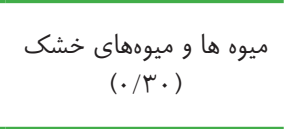 & & \\
\hline بيسكوئيت شور، جوب شور، جيميس، يِكى، خيار شور و سبزيجات شور، زيتون & ميان وعدههاى شور (I/T/.) & & \\
\hline كره، ماركارين، دنبه، خامه و سرشير، روغن نباتى جامد، روغن حيوانى & منابع جربى اشباع وترانس (Yq/ - -) & & \\
\hline 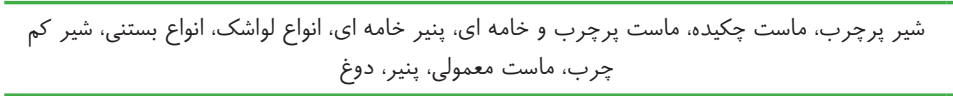 & 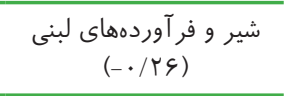 & & \\
\hline 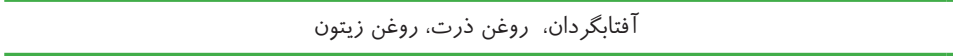 & 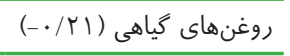 & & \\
\hline 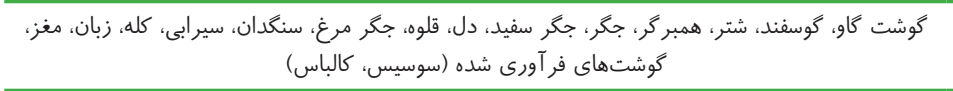 & 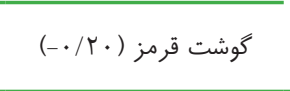 & & \\
\hline خيار، بادمجان، ييازخام، يياز سرخ شده، سبزى خوردن، سبزى خورشتى، سبزى آش، لوبيا سبز، نخو دفرنكى، باقلا، كدو & 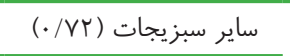 & \multirow{13}{*}{ 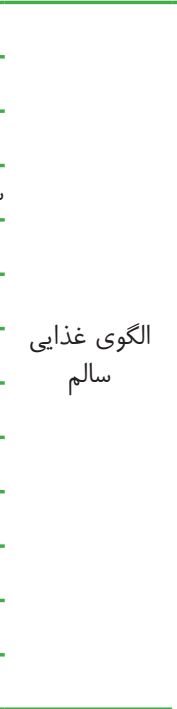 } & \multirow{29}{*}{ 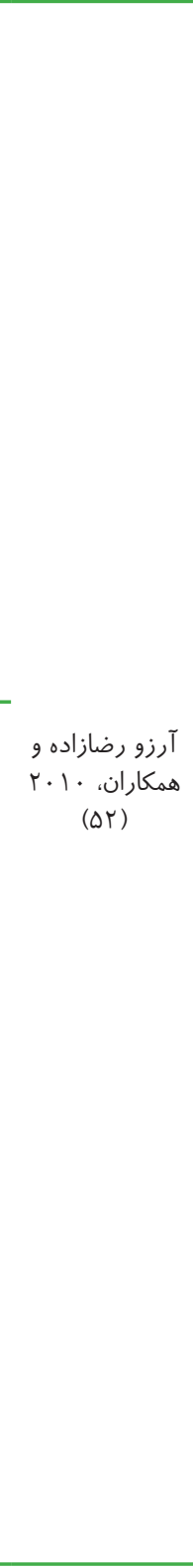 } \\
\hline طالبى، هندوانه، خربزه، گوجه سبز، سيب، زردآلو، آلو زرد، الو قرمز، كيلاس، آلبالو، شليل، هلو، كلابى، انجير، بر تقال، نارنكى، & 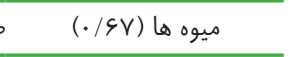 & & \\
\hline هويج & 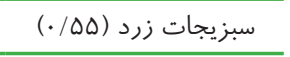 & & \\
\hline هر نوع كلم & 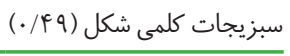 & & \\
\hline كوجه فرنگى، فراورده هاى تهيه شده از گوجه فرنگى ( سس قرمز ، رب گوجه فرنگى) & 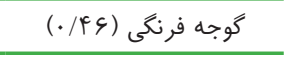 & & \\
\hline غو & 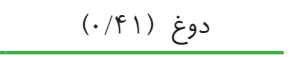 & & \\
\hline شير كم جرب، شير بدون جربى، ماست كم جرب، ماست معمولى ، پينير سفيد، كشى & 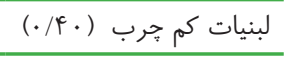 & & \\
\hline مرغ و جوجه & 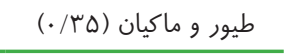 & & \\
\hline زيتون سبز، روغن زيتون & 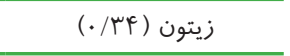 & & \\
\hline آب گريب فروت، آب يرتقال، آب سيب، آب طالبى، آب هويج، آبليمو، آبغوره، ساير & آبميوههاى طبيعى (YN/.) & & \\
\hline سيب زمينى & 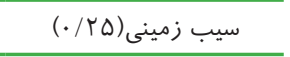 & & \\
\hline سير & 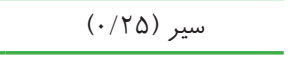 & & \\
\hline 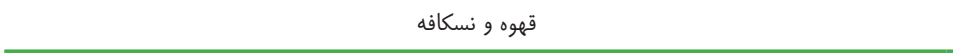 & قهوه & & \\
\hline سوسيس، كالباس & كوشتهاى فرآورى شده(DF/.) & \multirow{16}{*}{ 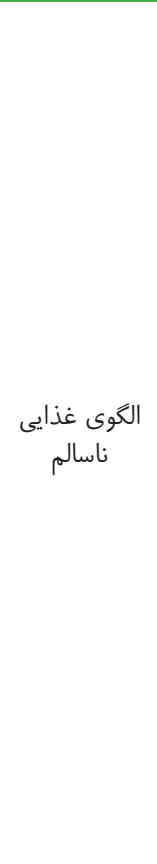 } & \\
\hline 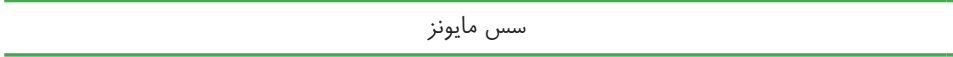 & 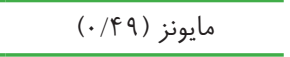 & & \\
\hline نوشابه & 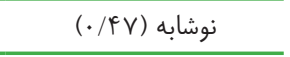 & & \\
\hline انواع كيك ، كلوحه ، شيرينى خشك، شيرينى تر & شيرينى ها و دسرها (سF/F) & & \\
\hline نان لواش، نان باكَ، برنج، ماكارونى، ورميشل،رشته، آرد كندم & غلات تصفيه شده (IF/.) & & \\
\hline بيسكويت، كراكر،يفك، جِيس & 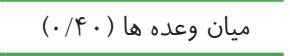 & & \\
\hline آبميوه صنعتى & آب ميوههاى صنعتى (Yr/.) & & \\
\hline كوشت كاو و گوساله، گوشت گوسفند، گوشت جرخ كرده، همبر & 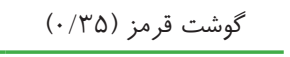 & & \\
\hline بادام زمينى، بادام، كردو، يّته، فندق، هرنوع تخمه، كنجد & 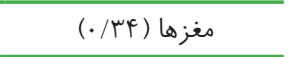 & & \\
\hline س & 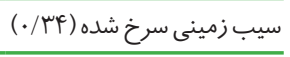 & & \\
\hline روغن نباتى جامد، روغن حيوانى جامد، بِيه & 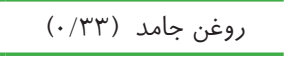 & & \\
\hline 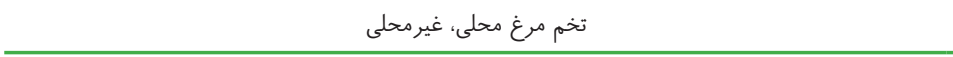 & 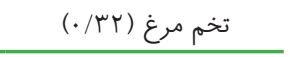 & & \\
\hline 0,5 & $(\cdot / \mu r)_{0}$ & & \\
\hline 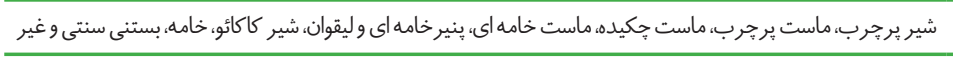 & لبنيات يرجرب (اس/·) & & \\
\hline شكر، قند، شكر پينير، گز، سوهان، ابنبات ، نبات، نقل، حلوا شكرى، شكلات كاكائو، تافى، عسل، مربا & 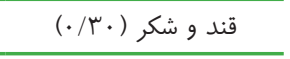 & & \\
\hline دل، جكر و قلوه، زبان و مغز، كله و ياجه، سيرابى و شيردان & كوشت احشاء (·r/·) & & \\
\hline
\end{tabular}


ادامه جدول أ: اقلام غذايى، گر وههاى غذايى در الكوهاى غذايى كه با متغيرهاى خاقى رابطه معنى دار داشتند

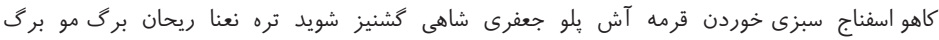

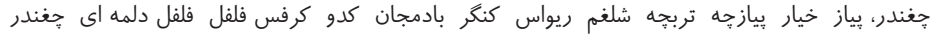

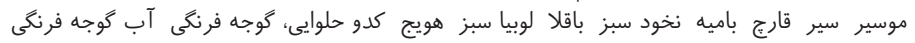

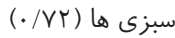

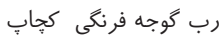

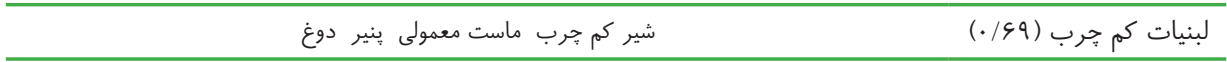

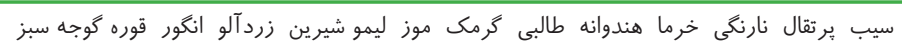

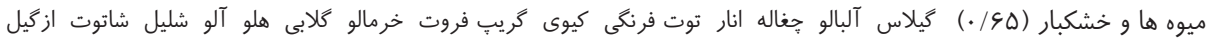

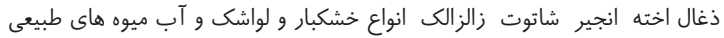

\begin{tabular}{|c|c|c|c|}
\hline نخودجى گردو فندق بادام يسته بادام زمينى بادام هندى انواع تخمه ها كنجد & مغزها و تخمه ها (109/•) & \multirow{8}{*}{ 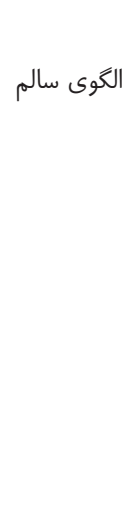 } & \multirow{14}{*}{ 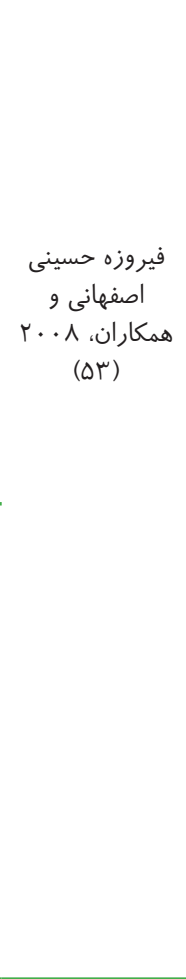 } \\
\hline آفتابكردان روغن ذرت روغن زيتون و زيتون & روغن مايع و زيتون (FV/.) & & \\
\hline ماهى ، تن ماهى - مرغ (تمام روش هاى آماده سازى) & 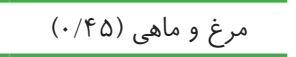 & & \\
\hline & 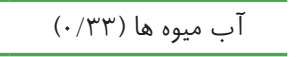 & & \\
\hline 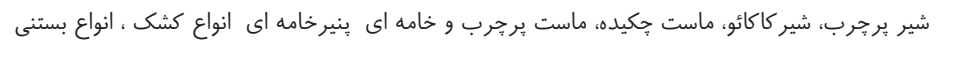 & 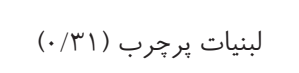 & & \\
\hline نان سنگك تافتون بربرى كورن فلكس نان جو جو گندم بلغور جوانه ذرت شاهدانه & 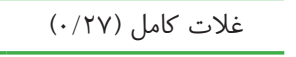 & & \\
\hline 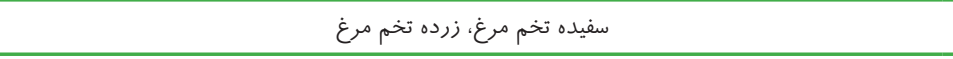 & 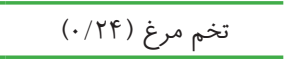 & & \\
\hline انواع مرباها و كميوت ها، شيره، ارده، عسل & مربا، كميوت، عسل و شيره & & \\
\hline بيسكويت شور، جوب شور، جيميس، ٍِفك، خيارشور و سبزيجات شور & ميان وعدههاى شور (\$9/.) & \multirow{6}{*}{ 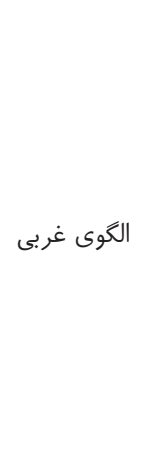 } & \\
\hline 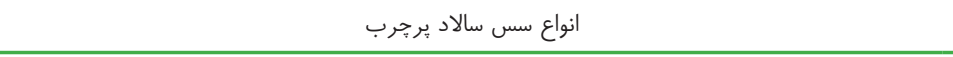 & 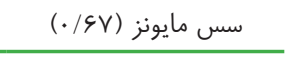 & & \\
\hline ناركيل كره ماركارين دنبه خامه و سرشير روغن نباتى جامد روغن حيوانى، & 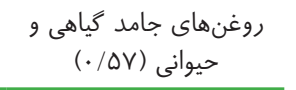 & & \\
\hline 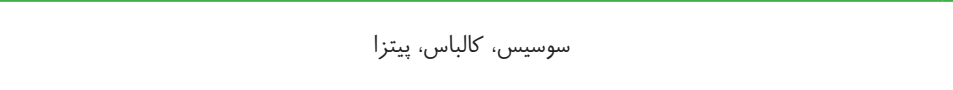 & 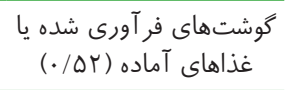 & & \\
\hline نان لواش نان باكت نان بستنى نشاسته آرد كندم نان شيرمال برنج آرد برنج ماكارونى رشته ورميشل & غلات تصفيه شده (Tr/.) & & \\
\hline انواع آب ميوههاى صنعتى و با شكر افزوده، ماءالشعير، نوشابه ها، شربت ها & نوشابههاى شيرين شده (r/r/.) & & \\
\hline
\end{tabular}

$$
\text { بحث و نتيجاه كيرى }
$$

ديخرى، الخوهاى متفاوتى دراستانهاى مختلف ايران در سكونتهاى روستايى و شهرى معرفى شدند (T/). با توجه به بار عاملى گروههاى غذايى در الخوهاى شناسايى شده، الخوهاى مشخص مانند مطالعات قبلى درايران و مطالعات انجام شده در ساير كشورها بصورت (سالم)) يا (ناسالم)) حاصل نشد. با توجه به تنوع مصرف گروههاى مواد غذايى

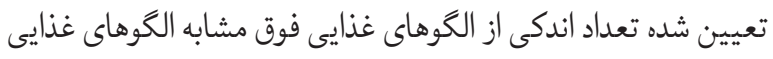
سالم و به ميزان كمترى مشابه الخوى غذايى ناسالم و تعداد زيادى از الكوهاى غذايى روستايى و شهرى شناسايى شده مشابه الكوهاى غذايى تحت عناوين ((سنتى))، ((مخلوط))، ((متنوع)) يا ((اكوناگون)) در مطالعات قبلى در ايران و ساير كشورها بود.
يُّوهش حاضر با مطالعه اي را كه الخوهاى غذايى بزركسالان شهر تهوان را گزارش و ارتباط اين الخوها با متغيرهاى جاقى را بررسى كرده

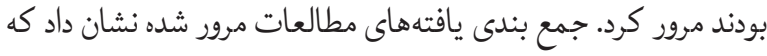
الخوهاى غذايى مصرفى مرتبط با شاخصهاى جاقى در بزرگسالان

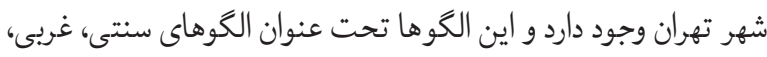
سالم، ناسالم و تخم مرغ نامخذارى شده بودند. در مطالعه مرور نظام مند ميرميران و همكاران (T) كه هدف آنها معرفى الخوهاى رايج بزرگسالان ايران و رابطه الكوها با بيمارىهاى مزمن بود، سه الخوى غذايى سالم، غربى و سنتى مرتبط با بيمارىهاى مزمن بزرگسالان ايران معرفى شد كه همراستا با يافته مطالعه حاضر است. در مطالعه 
است با الكوى تعريف شده از الكوى غربى نشانه مصرف بالاى

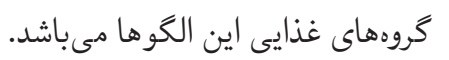
اثرات كلى اجزاى الحوى غذايى غربى با افزايش خطر ابتلابه

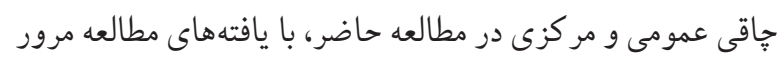

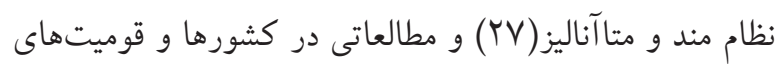

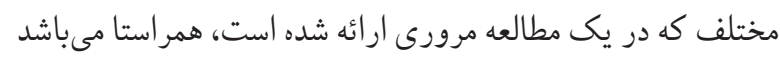

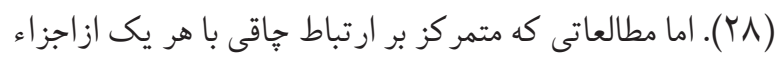

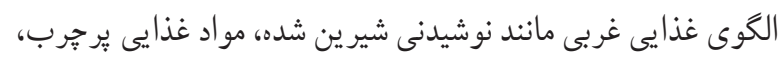
لبنيات است، شواهد همكونى ارائه نداده است.

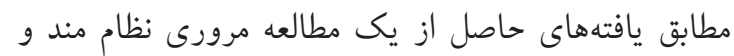

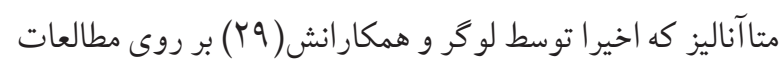

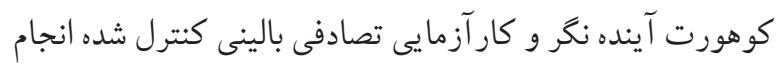

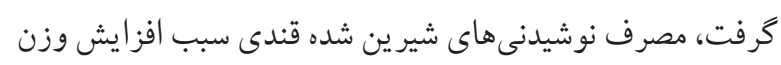

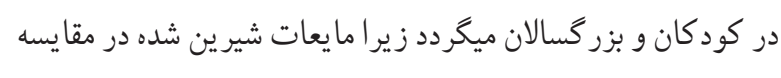

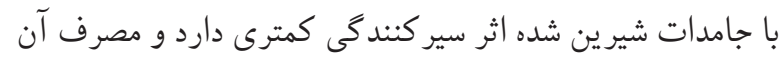

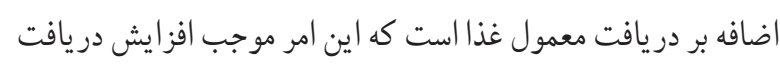

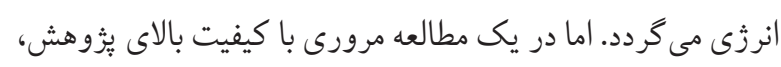

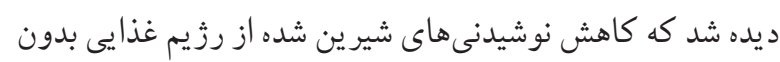

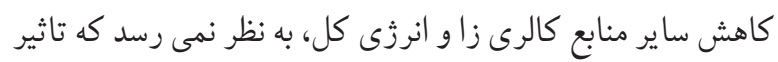

معنى دارى در كاهش بيمارىهاى مزمن داشته باشد ( •r).

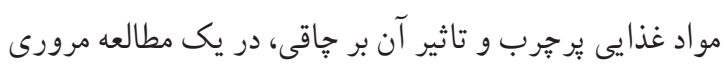

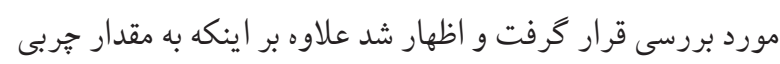

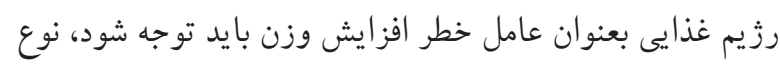

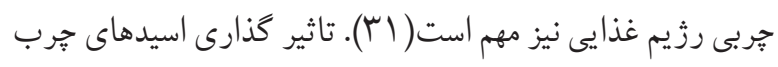

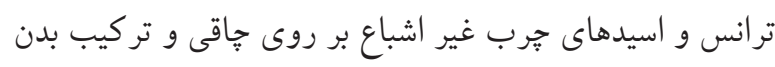

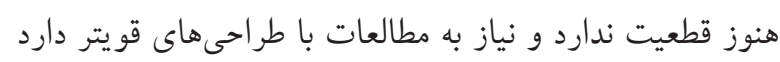

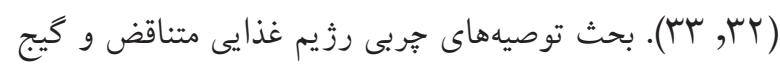

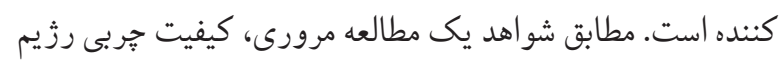

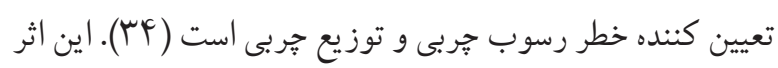

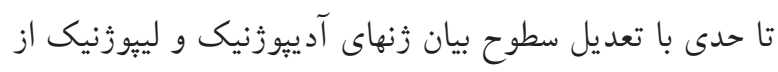

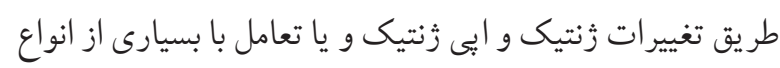

آنجه در مقايسه اين مطالعات قابل ذكر است اينكه الكوهاى غذايى بر اساس گروههاى غذايى هر عامل نام كذارى شده است كه اين گروه بندى استاندارد سازى نشده و در مطالعات مختلف يكسان

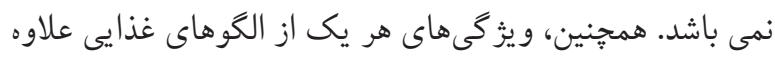

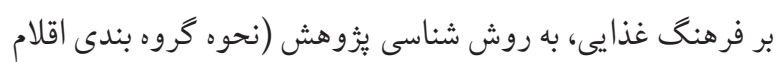

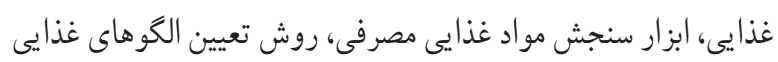
و غبره) بستكى دارد كه مقابسه يافته ها را با خالش مواجه مى نمايد.

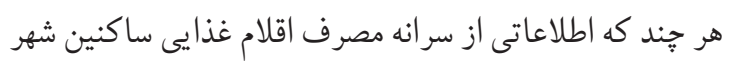
تهران در سالهاى اخيردر دسترس نمى باشد اما مطالعه حاضر نشان

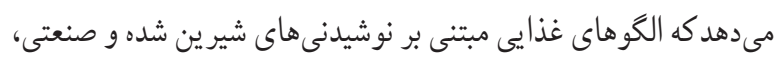
ميان وعدههاى شور، گوشت فر آورى شده، غلات تصفيه شده و غير غيره

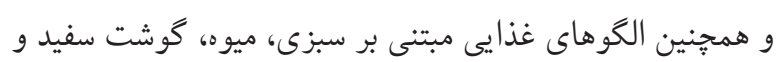
غيره از الكوهاى غذايى رايج در يزر گسالان شهر تهران مىباشد. با معرفى الكوهاى غذايى مرتبط با جاقى در جامعه بزر كسال

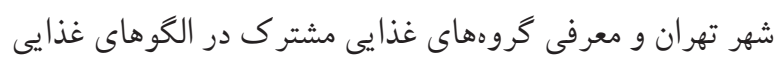

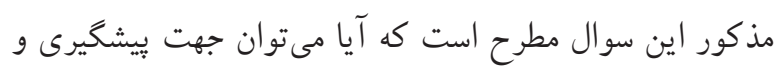

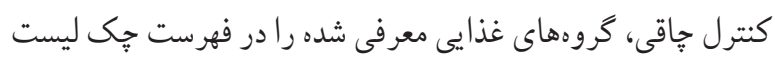

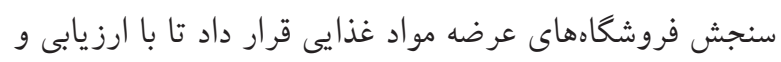
سنجش محيط غذايى جامعه، تصويرى از وضعيت دسترسى به اقلام

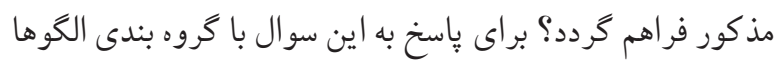

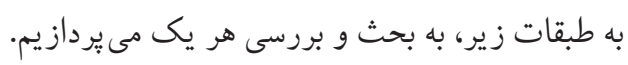

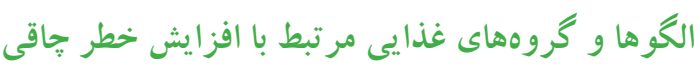

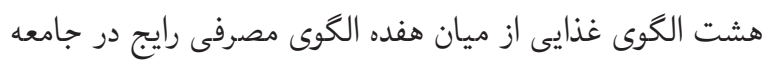

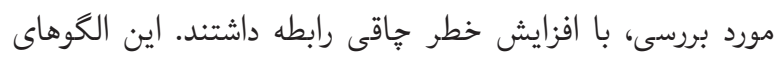

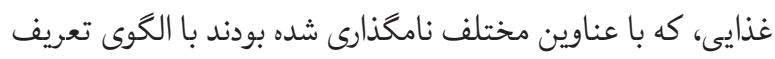

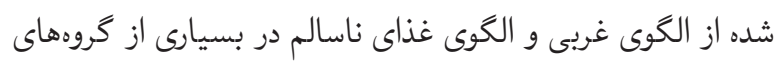
غذايى مشابهت داشتند. در تعريفى كه از الخوى غربى شده است، اين الكو داراى مشخصه مصرف بالاى گوشت قرمز، غلات تصفيه شده، گوشت فرآورى شده، محصولات لبنى با جربى بالا، دسرها،

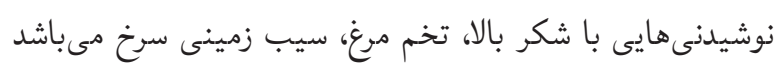
(YY-MY) 
در مطالعه حاضر علاوه بر الخَوى غربى، الكوى سنتى نيز با جاقى رابطه مثبت نشان داد. الكوى غذايى كه در دو مطالعه شر افت كاظم زاده(؟) و اسماعيل زاده(؟) تحت عنوان الخوى غذايى سنتى

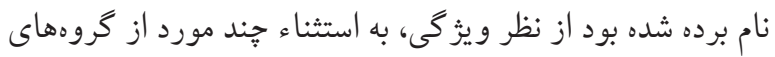
غذايى، كاملا با يكديكر يكسان نيستند. اين اختلاف مى تواند بدليل تفاوت نظر محققين در نامخذارى و يا روش شناسى مطالعه باشد. الخوى استخراجى مطالعه شر افت كاظم زاده و همكاران با استفاده از رگرسيون رتبه بندى كاهش يافته بر مواد مغذى، بيشترين بار

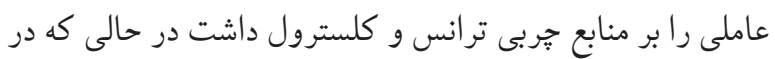

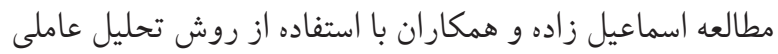
بر گروههاى غذايى بيشتر ين بار عاملى بر گروه سيب زمينى، غلات

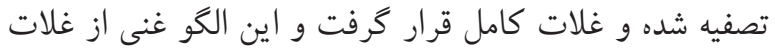
تصفيه شده، سيب زمينى، جاى، روغنهاى جامد هيدروزنه بود.

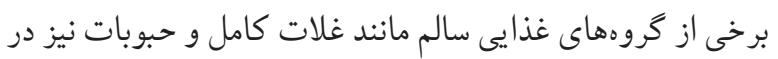
اين الخوى غذايى مشاهده شد كه ممكن است با ساير اجزاى اين

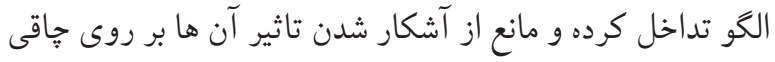
شود. با توجه به اينكه غلات كامل از اجزاء الكوى غذايى سنتى و الكوى غذايى سالم در بزر كسالان شهر تهران بود بنابراين نتايج

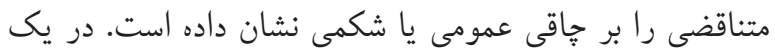
مطالعه مقطعى كه اسماعيل زاده و همكارانش ( • F) در شهر تهران انجام دادند يّ از كنترل عوامل مخدوشكر، ارتباط منفى را بين دريافت غلات كامل با شاخصهاى تن سنجى مشاهده كردند اما

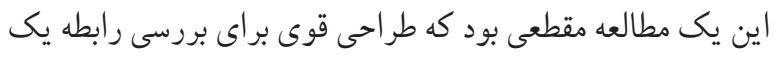

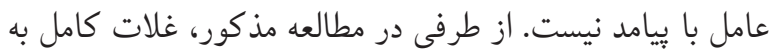
صورت مجموع نان سنگك، نان تافتون، نان بربرى، كورن فلكس، نان جو، جو، گندم، بلغور، جو انه ذرت و شاهدانه تعريف شده بود

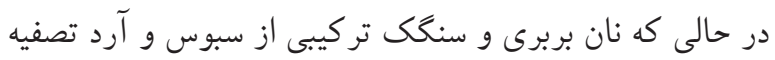

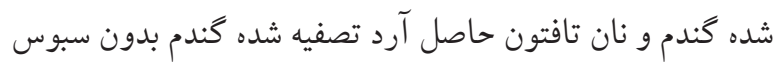

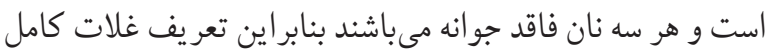

زُنتيك، هدايت مىشود. اما مطالعات بالينى بيشترى براى تأييد

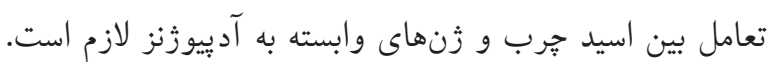
تعامل زن - اسيد جرب ممكن است در نهايت منجر به استفاده

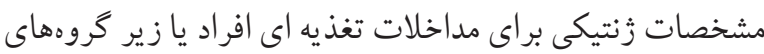

جمعيت شود(T)

لبنيات از اقلام غذايى بحث انكيز است. در ايامى كه بسيارى از مواد غذايى بصورت سالم و با ناسالم تلقى مىشوند اما لبنيات

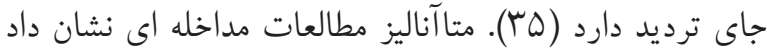
كه مصرف زياد لبنيات بدون محدوديت دريافت انرزى مى تواند

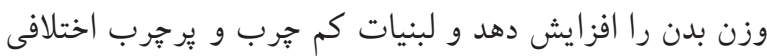

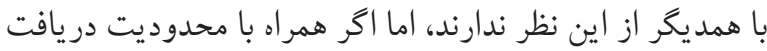
انرزى باشد وزن بدن و توده جربى را كاهش مىدهد (4)). اكر جه.

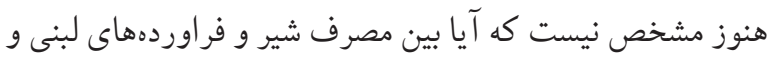

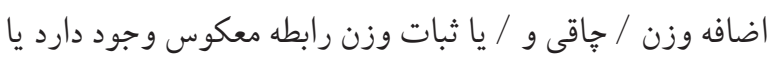

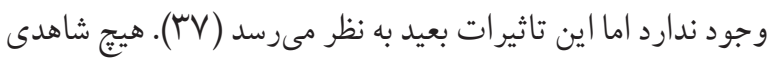
مبنى بر مصرف لبنيات كم جرب در اين باره فوايدى داشته باشد.

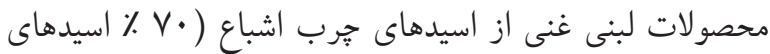
جرب) و فقير از اسيدهاى جرب جند غير اشباع هستند و باو وجود

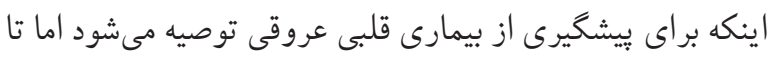

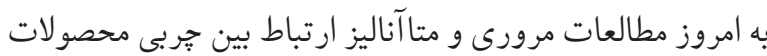
لبنى و خطر بيمارى ها قلبى عروقى راضعيف يا خنثى كزارش كرده

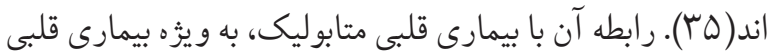

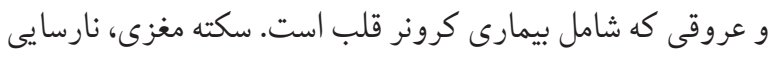
قلبى، و بيمارى عروق محيطى، مدت ها موضوع تحقيق است و با وجود بسيارى از نشريات علمى، هيج توافقى حاصل نشده است سترون

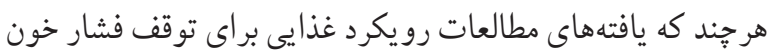
بالا و رزيم مديترانه اى نشان داد كه شير و محصولات لبنى ينى كه از

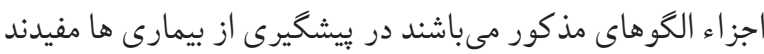

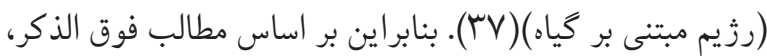
الكوى غذايى غربى شايد با جاقى رابطه داشته باشد اما ممكن است اين رابطه با هر يك از اجزاء آن ديده نشود. 
شده، مواد غذايى شير ين شده با شكر، نوشيدنى و غلات تصفيه شده با وضعيت مطلوب تر وزن بدن، اندك و غيرقطعى است(

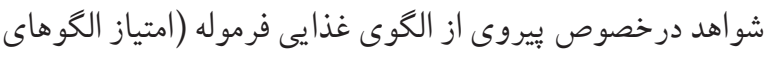
غذايى با مشخصه دريافت بالاى ميوه ها، سبزيجات، غلات كامل،

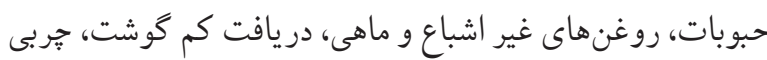

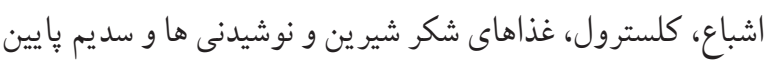

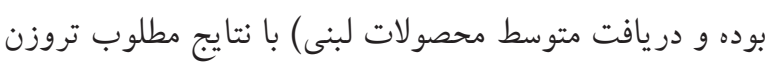

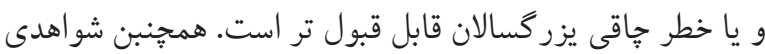

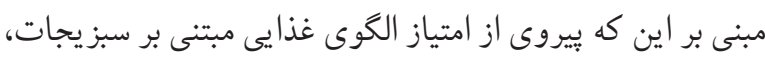

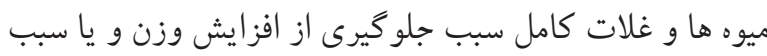

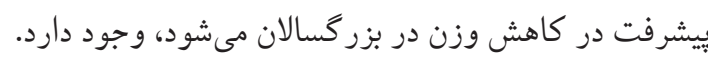

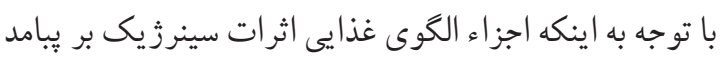

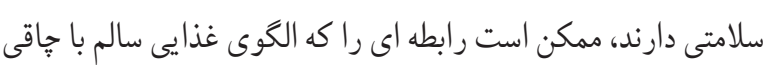

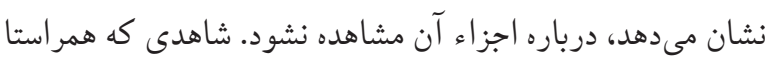

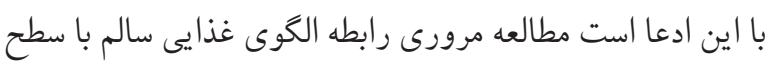

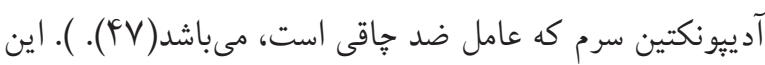
مطالعه نشان داد، الكوى غذايى سالم مانند رزيم غذايى مديترانه

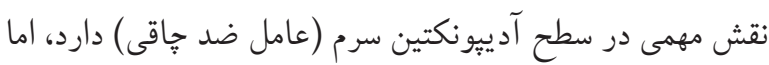
اين تاثير درباره اجزاء الخوهاى غذايى سالم نامشخص است.

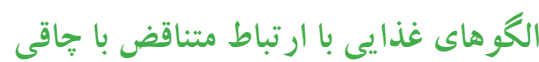

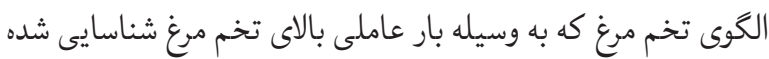

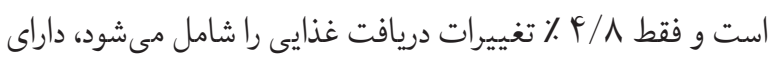
تاثيرات تا حدى متناقض بر كاهش نمايه توده بدن به خصوص در زنان و افزابش نسبت دور كمر به باسن در هر دو جنس زن و مردد داشته

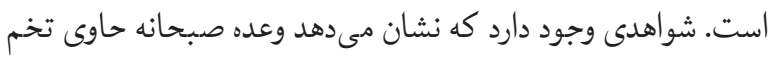
مرغ، بدليل تاثيرى كه بر اشتهاء و سيرى دارد، در كاهش مصرف كل

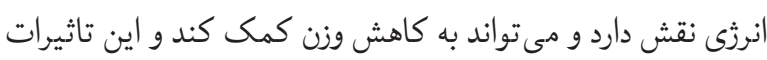

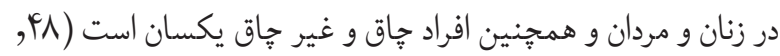

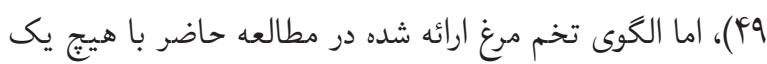

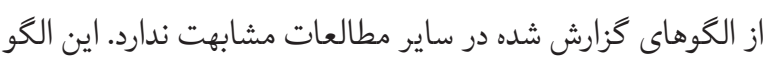

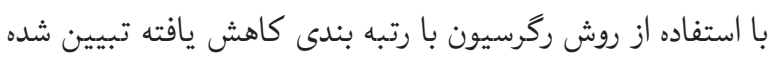

كه تشكل از سبوس '، جو انه '، درون دانه باست را شامل نمى شود. تعريف "نان دانه كامل غلات" در مطالعات إيدميولوزيك و تاثير شيوههاى سنتى محصولات نان بر وزن و تنظيم متابوليسم ارائه شده

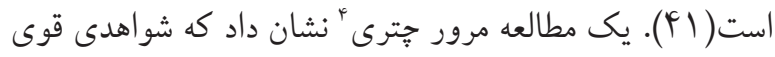

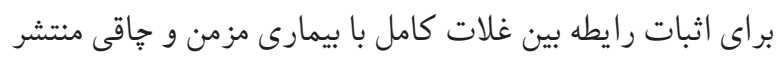

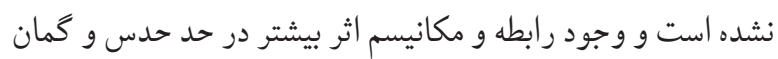

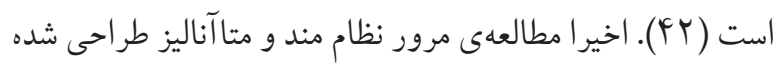

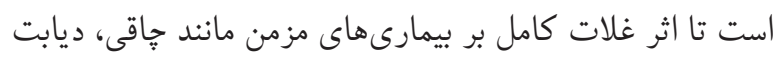
نوع لَ، بيمارى قلبى عروقى و فشارخون، مكانيسم اثر غلات كامل

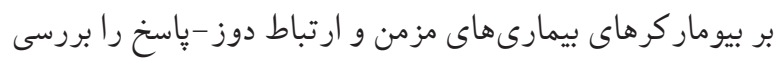

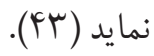

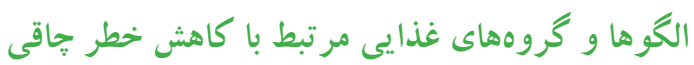
در اين مطالعه، هشت الكوى غذايى تحت عنوان الكوهاى غذايى

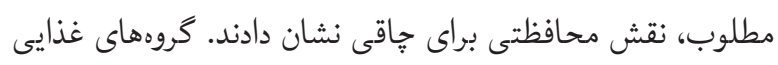

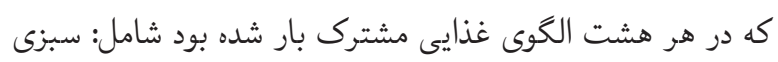

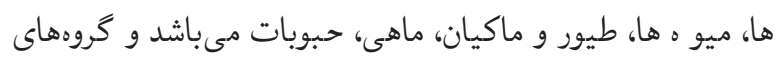

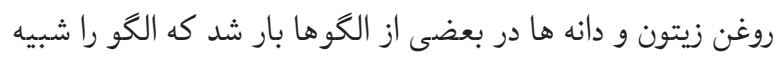
الكوى مديترانه مىنمايد. تفاوت درون گروهى (هشت الكوى ايرانى)

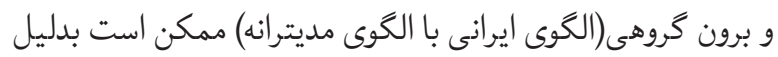
تفاوت در جمعيت مورد بررسى و فرهنگ غذايى باشد. مطالعات ديخر تفاوت ها را در بين الكوهاى رثيم غذايى مردان و زنان مشاهده

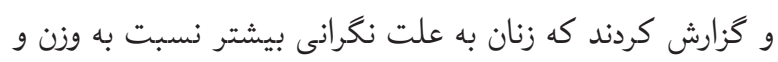

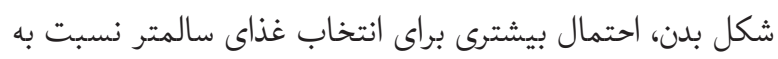

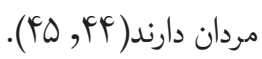
اين هشت الكو هر جند نقش محافظتى را نشان مىدهند اما شو اهد در خصوص ارتباط معكوس الكوهاى رزيم غذايى حاصل از تحليل

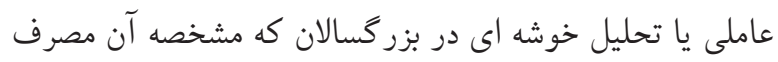

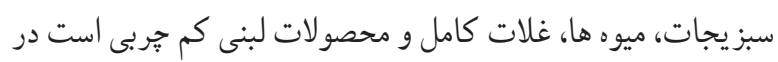

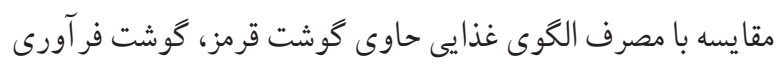

\section{1. bran}

2. germ

3. endosperm

4. Umbrella Review 
حاضر و يا مستندات علمى مشابه در طراحى جّى ليست سنجش فروشكاههاى عرضه مواد غذايى براى برقرارى نظام پايش و نظارت

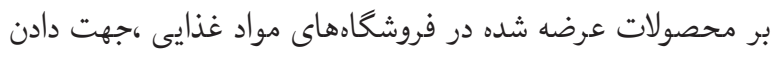
توليدات صنايع غذايى و كشاورزى به سمت بهبود توليدات گروههاى

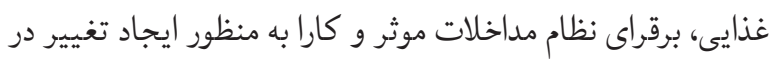

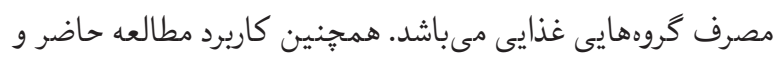
مطالعات مشابه در سياستخذارى نظام غذا و تغذيه، اهميت جايگاه كروه بندى اقلام غذايى را نمايان مىسازد و ييشنهاد مى گردد كه كروه بندى به شيوه يكسان و مطابق استاندارد معينى انجام شود.

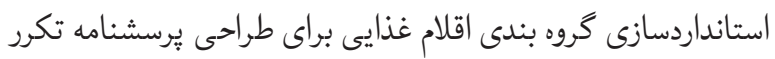

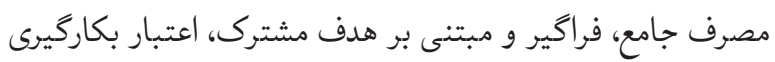
اين ابزار را افزون مىبخشد. تشكر و قدردانى: اين تحقيق توسط دانشخاه علوم بزشكى ايران

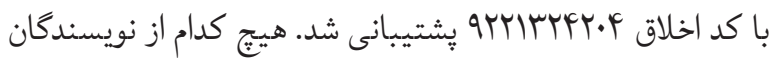
اين مطالعه، تعارض منافعى براى انتشار اين مقاله ندارند. بدينوسيله از افرادى كه ما را در اين مطالعه يارى نمودند، صميمانه تشكر و قدردانى مى گردد. تضاد در منافع: بين نويسندگان هيج گونه تعارضى در منافع جاب

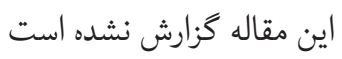

\section{References}

1. Keikha F, Ansari $H$, khosravi M, Seraji M. The Effect of Educational Intervention on Health Literacy and Nutritional Performance of Female High School Students in Zahedan. Journal of Health Literacy. 2021;6(1):41-50.

2. Aghdasi Z, Tehrani H, Esmaiely H, Ghavami M, VahedianShahroodi M. Application of social cognitive theory on maternal nutritional behavior for weight of children 6 to 12 months with Failure to thrive (FTT). Iranian Journal of Health Education and Health Promotion. 2021;9(2):145-58.:42. https://doi.org/10.52547/ijhehp.9.2.145

3. Wharton S, Lau DC, Vallis M, Sharma AM, Biertho L, Campbell-Scherer $D$, et al. Obesity in adults: a clinical practice guideline. CMAJ. 2020; 192(31):E875-91. https: / / doi.org/10.1503/cmaj. 191707 PMid:32753461 PMCid:PMC7828878

4. Sheikh AB, Nasrullah A, Haq S, Akhtar A, Ghazanfar H, Nasir
است كه از نظر متدولوزى با ساير مطالعات متفاوت است. ماهيت

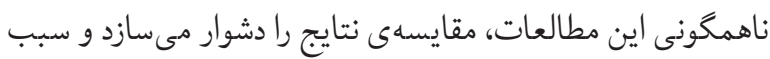
مىشود كه نتوان يك نتيجه گيرى نهايى بدست آورد.

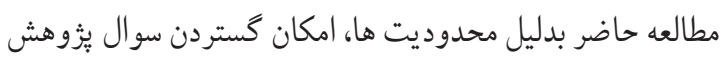

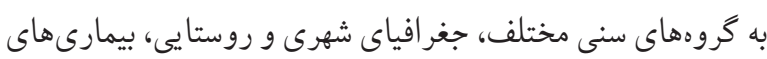

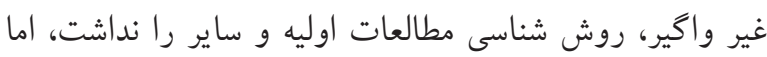

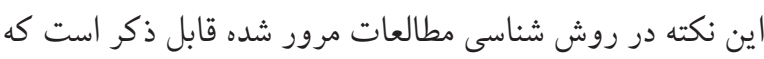

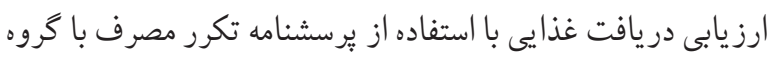

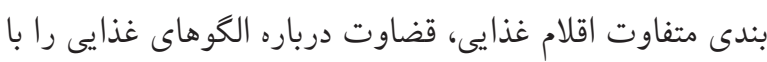
محدوديتهايى روبرو مىسازد.

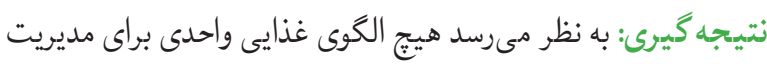

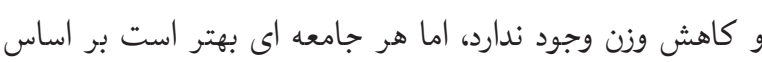

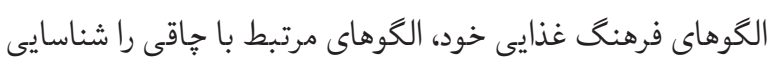
نمايد. يافتهاى مطالعه حاضر نشانكر رواج الخوى غذايى مرتبط با جاقى در بزرگسالان شهر تهران است و الخوهاى غذايى افراد

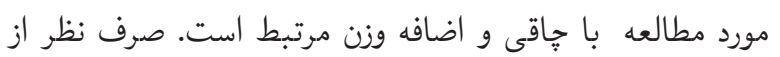

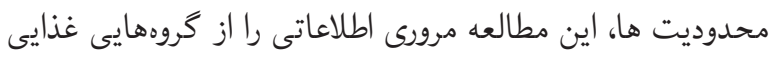

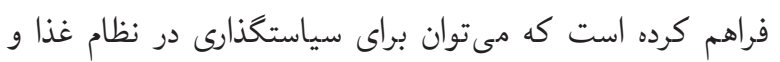

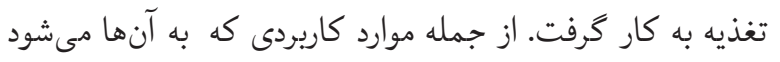

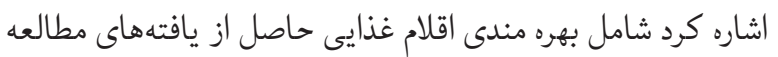

A, et al. The interplay of genetics and environmental factors in the development of obesity. Cureus. 2017; 9(7). https://doi.org/10.7759/cureus.1435

5. Vernarelli JA, Mitchell DC, Rolls BJ, Hartman TJ. Dietary energy density and obesity: how consumption patterns differ by body weight status. Eur J Nutr. 2018; 57(1):351-61. https://doi.org/10.1007/s00394-016-1324-8 PMid:27738811

6. Turner C, Kalamatianou S, Drewnowski A, Kulkarni B, Kinra S, Kadiyala S. Food Environment Research in Low- and Middle-Income Countries: A Systematic Scoping Review. Adv Nutr. 2020; 11(2):387-97. https://doi.org/10.1093/advances/nmz031 PMid:31079142 PMCid:PMC7442349

7. Jassemi Zergani $M$, Seirafi M-R, Taghdisi $M-H$, Malihi zuckerini S, Taghavi-Kojeidi H. Evaluation of effectiveness 
of integration of Mindfulness-Based-Eating Awareness Training and implementation intention model on Body Mass Index, Waist circumference, Mindfulness Eating, and Physical Activity in Obese Women. Iranian Journal of Health Education and Health Promotion. 2021;9(1):94-109. https://doi.org/10.52547/ijhehp.9.1.94

8. Hawkes C. Dietary implications of supermarket development: a global perspective. Dev Policy Rev. 2008; 26(6):657-92. https://doi.org/10.1111/j.1467-7679.2008.00428.x

9. Pestoni G, Krieger J-P, Sych JM, Faeh D, Rohrmann S. Cultural differences in diet and determinants of diet quality in Switzerland: Results from the national nutrition survey menuCH. Nutrients. 2019; 11(1):126. h tt p s : / / doi .org / $10.3390 /$ nu 11010126 PMid:30634520 PMCid:PMC6357532

10. Govindaraju T, Sahle BW, McCaffrey TA, McNeil JJ, Owen AJ. Dietary patterns and quality of life in older adults: A systematic review. Nutrients. 2018; 10(8):971. h tt p s: / / doi .org/10.3390/nu10080971 PMid:30050006 PMCid:PMC6115962

11. Rezagholizadeh F, Djafarian K, Khosravi S, Shab-Bidar S. A posteriori healthy dietary patterns may decrease the risk of central obesity: findings from a systematic review and meta-analysis. Nutr Res. 2017; 41:1-13 https://doi.org/10.1016/j.nutres.2017.01.006 PMid:28577788

12. Vahedian-Shahroodi $M$, Tehrani $H$, Robat-Sarpooshi $D$, GHolian-Aval M, Jafari A, Alizadeh-Siuki H. The impact of healtheducationonnutritionalbehaviorsinfemalestudents: An application of health belief model. International Journal of Health Promotion and Education. 2021;59(2):70-82.. https://doi.org/10.1080/14635240.2019.1696219

13. Naska A, Lagiou A, Lagiou P. Dietary assessment methods in epidemiological research: current state of the art and future prospects. F1000research. 2017; 6:626. https://doi.org/10.12688/f1000research.10703.1 PMid:28690835 PMCid:PMC5482335

14. Reedy J, Subar AF, George SM, Krebs-Smith SM. Extending methods in dietary patterns research. Nutrients. 2018; 10(5):571. https: / / doi.org/10.3390/nu10050571 PMid:29735885 PMCid:PMC5986451

15. Shahinfar $H$, Safabakhsh $M$, Babaei N, Ebaditabar $M$, Davarzani S, Amini MR, et al. Association of major dietary patterns with muscle strength and muscle mass index in middle-aged men and women: Results from a cross-sectional study. Clin Nutr ESPEN. 2020; 39:215-21. https://doi.org/10.1016/j.clnesp.2020.06.010

\section{PMid:32859319}

16. Mousavizadeh Z, Hosseini-Esfahani F, Javadi A, Daneshpour MS, Akbarzadeh $M$, Javadi $M$, et al. The interaction between dietary patterns and melanocortin-4 receptor polymorphisms in relation to obesity phenotypes. Obes Res Clin Pract. 2020; 14(3):249-56. https://doi.org/10.1016/j.orcp.2020.04.002 PMid:32446744

17. Mirzababaei A, Sajjadi SF, Ghodoosi N, Pooyan S, Arghavani H, Yekaninejad MS, et al. Relations of major dietary patterns and metabolically unhealthy overweight/obesity phenotypes among Iranian women. Diabetes Metab Syndr. 2019; 13(1):322-31. https://doi.org/10.1016/j.dsx.2018.09.012 PMid:30641720

18. Tangestani H, Emamat H, Yekaninejad MS, Keshavarz SA, Mirzaei K. Variants in Circadian Rhythm Gene Cry1 Interacts with Healthy Dietary Pattern for Serum Leptin Levels: a Cross-sectional Study. Clin Nutr Res. 2021; 10(1):48-58. https://doi.org/10.7762/cnr.2021.10.1.48 PMid:33564652 PMCid:PMC7850819

19. Arksey H, O'Malley L. Scoping studies: towards a methodological framework. Int. J. Soc. Res. Methodol. 2005; 8(1):19-32. https://doi.org/10.1080/1364557032000119616

20. Herzog R, Álvarez-Pasquin MJ, Díaz C, Del Barrio JL, Estrada JM, Gil Á. Are healthcare workers' intentions to vaccinate related to their knowledge, beliefs and attitudes? A systematic review. BMC Public Health. 2013; 13(1):1-17 https://doi.org/10.1186/1471-2458-13-154 PMid:23421987 PMCid:PMC3602084

21. Wells GA, Shea B, O'Connell D, Peterson J, Welch V, Losos $M$, et al. The Newcastle-Ottawa Scale (NOS) for assessing the quality of nonrandomised studies in meta-analyses. Available from: http://www.ohri.ca/programs/clinical_ epidemiology/oxford.asp

22. Mirmiran P, Ghohroudy AF, Niazi SH, Ahmadi B, Nayeri F, Azizi F. Dietary Patterns and Non Communicable Disease among Iranian Women: A Systematic Review. Women's Health Bull. 2014; 1(3):1-8. https://doi.org/10.17795/whb-21358

23. Ezatifar A. Study of household major dietary patterns and their association with overweight and obesity in Iranian adults [dissertation]. Tehran: Faculty of Nutrition Sciences and Food Technology, Shahid Beheshti University of Medical Sciences; 2016.

24. Fung TT, Schulze M, Manson JE, Willett WC, Hu FB. Dietary patterns, meat intake, and the risk of type 2 diabetes 
in women. Arch Intern Med. 2004; 164(20):2235-40. https://doi.org/10.1001/archinte.164.20.2235 PMid:15534160

25. Montonen J, Knekt P, Harkanen T, Jarvinen R, Heliovaara $M$, Aromaa A, et al. Dietary patterns and the incidence of type 2 diabetes. Am. J. Epidemiol. 2005; 161(3):219-27. https://doi.org/10.1093/aje/kwi039 PMid:15671254

26. Van Dam RM, Rimm EB, Willett WC, Stampfer MJ, Hu FB. Dietary patterns and risk for type 2 diabetes mellitus in U.S. men. Ann. Intern. Med. 2002; 136(3):201-9. https://doi.org/10.7326/0003$4819-136-3-200202050-00008$ PMid:11827496

27. Mu M, Xu LF, Hu D, Wu J, Bai MJ. Dietary Patterns and Overweight/Obesity: A Review Article. Iran. J. Public Health. 2017; 46(7):869-76.

28. Medina-Remon A, Kirwan R, Lamuela-Raventos RM, Estruch R. Dietary patterns and the risk of obesity, type 2 diabetes mellitus, cardiovascular diseases, asthma, and neurodegenerative diseases. Crit Rev Food Sci Nutr. 2018; 58(2):262-96. https://doi.org/10.1080/10408398.2016.1158690 PMid:27127938

29. Luger M, Lafontan M, Bes-Rastrollo M, Winzer E, Yumuk $V$, Farpour-Lambert N. Sugar-Sweetened Beverages and Weight Gain in Children and Adults: A Systematic Review from 2013 to 2015 and a Comparison with Previous Studies. Obes Facts. 2017; 10(6):674-93. h ttps://doi.org/10.1159/000484566 PMid:29237159 PMCid:PMC5836186

30. Rippe JM, Angelopoulos TJ. Relationship between added sugars consumption and chronic disease risk factors: current understanding. Nutrients. 2016; 8(11):697. h tt p s: / / d o i . org / 10.3390 / nu 8110697 PMid:27827899 PMCid:PMC5133084

31. Moussavi N, Gavino V, Receveur O. Could the quality of dietary fat, and not just its quantity, be related to risk of obesity? Obesity (Silver Spring). 2008; 16(1):7-15. h tt p s : / / doi .org/10.1038/oby. 2007.14 PMid:18223605

32. Hastert TA, de Oliveira Otto MC, Lê-Scherban F, Steffen BT, Steffen LM, Tsai MY, Jacobs DR Jr, Baylin A. Association of plasma phospholipid polyunsaturated and trans fatty acids with body mass index: results from the Multi-Ethnic Study of Atherosclerosis. Int J Obes (Lond). 2018Mar;42(3):433-440. https://doi.org/10.1038/ijo.2017.282 PMid:29151597 PMCid:PMC5876070
33. Emamat H, Yari Z, Farhadnejad H, Mirmiran P. Differential effects of dietary fatty acids on body composition and adiposity. Curr Nutr Food Sci. 2020; 16(2):142-54. https://doi.org/10.2174/1573401314666181010100002

34. Hammad SS, Jones PJ. Dietary fatty acid composition modulates obesity and interacts with obesityrelated genes. Lipids. 2017; 52(10):803-22. https://doi.org/10.1007/s11745-017-4291-9 PMid:28889206

35. Yu E, Hu FB. Dairy Products, Dairy Fatty Acids, and the Prevention of Cardiometabolic Disease: a Review of Recent Evidence. Curr Atheroscler Rep. 2018; 20(5):24. https://doi.org/10.1007/s11883-018-0724-z PMid:29564646 PMCid:PMC5990967

36. Geng T, Qi L, Huang T. Effects of Dairy Products Consumption on Body Weight and Body Composition among Adults: An Updated Meta-Analysis of 37 Randomized Control Trials. Mol Nutr Food Res. 2018; 62(1). https://doi.org/10.1002/mnfr. 201700410 PMid:29058378

37. Pfeuffer M, Watzl B. Nutrition and health aspects of milk and dairy products and their ingredients. Ernahrungs Umschau. 2018; 65(2): 22-33.e14-e17. Available at: DOI: 10.4455/eu.2018.006

38. Sherafat-Kazemzadeh R, Egtesadi S, Mirmiran P, Hedayati $M$, Gohari M, Vafa M, et al. Predicting of Changes in Obesity Indices Regarding to Dietary Patterns in Longitudinal Tehran Lipid and Glucose Study. Iran. J. Endocrinol. Metab. 2010; 12(2):131-44.

39. Esmaeillzadeh A, Azadbakht L, Khoshfetrat MR, Kimiagar M. Major dietary patterns, general and central adiposity among Tehrani female teachers. Health system research. 2011; 6(4):676-89.

40. EsmaillzadehA, MirmiranP,Azizi F. Whole-grainconsumption and the metabolic syndrome: a favorable association in Tehranian adults. Eur J Clin Nutr. 2005; 59(3):353-62. https://doi.org/10.1038/sj.ejcn.1602080 PMid:15536473

41. Serra-Majem L, Bautista-Castano I. Relationship between bread and obesity. Br. J. Nutr. 2015; 113 Suppl 2:S29-35. https://doi.org/10.1017/S0007114514003249 PMid:26148919

42. McRae MP. Health Benefits of Dietary Whole Grains: An Umbrella Review of Metaanalyses. J Chiropr Med. 2017; 16(1):10-8. https://doi.org/10.1016/j.jcm.2016.08.008 PMid:28228693 PMCid:PMC5310957

43. Iqbal WA, Stewart GB, Smith AJ, Seal CJ. Protocol: The 
effect of whole-grain dietary intake on non-communicable diseases: A systematic review, multivariate meta-analysis and dose-response of prospective cohorts, cross-sectional, case-control and intervention studies. PeerJ Prepr. 2018. https://doi.org/10.7287/peerj.preprints.26710

44. Whittle CR, Woodside JV, Cardwell CR, McCourt HJ, Young IS, Murray LJ, et al. Dietary patterns and bone mineral status in young adults: the Northern Ireland Young Hearts Project. Br. J. Nutr. 2012; 108(8):1494-504. https://doi.org/10.1017/S0007114511006787 PMid:22214826

45. Xu S-H, Qiao N, Huang J-J, Sun C-M, Cui Y, Tian S-S, et al. Gender differences in dietary patterns and their association with the prevalence of metabolic syndrome among Chinese: a cross-sectional study. Nutrients. 2016; 8(4):180. h tt ps://doi .org/10.3390/nu 8040180 PMid:27023599 PMCid:PMC4848649

46. USDA. A series of systematic reviews on the relationship between dietary patterns and health outcomes. Alexandria: US Departmentof Agriculture; 2014.

47. Izadi V, Azadbakht L. Specific dietary patterns and concentrations of adiponectin. J Res Med Sci. 2015; 20(2): 178-184.

48. Rains TM, Leidy HJ, Sanoshy KD, Lawless AL, Maki KC. A randomized, controlled, crossover trial to assess the acute appetitive and metabolic effects of sausage and egg-based convenience breakfast meals in overweight premenopausal women. Nutr. J. 2015; 14(1):17. https://doi.org/10.1186/s12937-015-0002-7 PMid:25889354 PMCid:PMC4334852

49. B Keogh J, M Clifton P. Energy Intake and Satiety
Responses of Eggs for Breakfast in Overweight and Obese Adults-A Crossover Study. Int J Environ Res Public Health. 2020; 17(15):5583. https://doi.org/10.3390/ijerph17155583 PMid:32756313 PMCid:PMC7432073

50. Gorabi S. The association and the conteraction of priori and posteriori dietary patterns, some of adipokines and myoclines with components of metabolic syndrome [dessertation]. School of Nutritional Sciences and Dietetics: Tehran University of medical science; 2020.

51. Hosseini-Esfahani F, Koochakpoor G, Mirmiran P, Daneshpour MS, Azizi F. Dietary patterns modify the association between fat mass and obesityassociated genetic variants and changes in obesity phenotypes. $\mathrm{Br} J$ Nutr. 2019; 121(11):1247-54. https://doi.org/10.1017/S0007114519000643 PMid:30929646

52. Rezazadeh A, Rashidkhani B, Omidvar N. Evaluation of major dietary patterns and general and central obesity in adult women of north Tehran in 2007. Research in Medicine. 2010; 33 (4):246-258.

53. Hosseini Esfahani F, Mirmiran P, Djazayeri S, Mehrabi Y, Azizi F. Change in Food Patterns and its Relation to Alterations in Central Adiposity in Tehranian of District 13 Adults. Iran. J. Endocrinol. Metab. 2008; 10(4):299-312.

54. Mirmiran P, Djazayery A, Hosseini esfahani F, Mehrabi Y, Azizi $F$. Change in food patterns of Tehrani adults and its association with changes in their body weight and body mass index in District 13 of Tehran: Tehran Lipid and Glucose Study. Iranian Journal of Nutrition Sciences \& Food Technology. 2008; 2(4):67-80. 